\title{
THE RELATION OF GAMMARUS ZADDACHI SEXTON TO SOME OTHER SPECIES OF GAMMARUS OCCURRING IN FRESH, ESTUARINE AND MARINE WATERS
}

\author{
By E. W. Sexton, F.L.S.
}

From the Plymouth Laboratory

(Plates I-III, Text-fig. I)

\begin{tabular}{|c|c|c|c|c|c|c|c|c|c|c|c|c|c|c|c|}
\hline \multicolumn{16}{|c|}{ CONTENTS } \\
\hline & & & & & & & & & & & & & & & PAGE \\
\hline Introduction & . & . & . & . & . & & - & - & . & . & - & . & - & - & 575 \\
\hline Historical review & & . & . & . & . & & ${ }^{\circ}$ & ${ }^{\circ}$ & . & ${ }^{\circ}$ & . & . & - & $\cdot$ & $57^{8}$ \\
\hline Description of $G$ & Gam & naru & $z a c$ & achi & . & . & . & - & . & . & . & . & . & . & 593 \\
\hline Comparison of $t$ & the : & dult & nal & of $G$ & $a m$ & & $a d c$ & $i i$ & t & for & oth & & es & & \\
\hline$n$ & is & st & & Pan & & & - & - & . & . & . & - & . & $\cdot$ & $6 c$ \\
\hline Summary & . & . & . & . & . & . & . & . & . & . & . & . & - & · & 60 \\
\hline References & . & . & . & . & - & . & . & - & . & . & . & . & . & - & 60 \\
\hline Explanation of $\mathrm{P}$ & Plat & s I- & & . & - & . & . & . & . & . & . & . & . & . & \\
\hline
\end{tabular}

\section{INTRODUCTION}

Gammarus zaddachi, the species under discussion in this paper, is one of the most widely spread of the amphipods which inhabit the estuarine waters of northern Europe. It has been recorded in the river mouths and adjacent seas from the White Sea, along the Baltic, the coasts of Scandinavia, Prussia, the Netherlands, Great Britain and France and from the Crimean region also. Most of the early records are under the name of $G$. locusta, but many of these I have been able to revise, having had access to several large collections, housed in the British Museum, the Königsberg and Hamburg Museums and others.

This species has always been confused with $G$. locusta-why, it is difficult to say, as the characters are quite distinct. Their habitats also are different, locusta being a marine species, and zaddachi typically brackish water, though there may be a little overlapping at the seaward limit of its range. The discovery referred to below, of the difference in the development of the sensory armature of the cuticle in relation to the environment, may perhaps account for some of the confusion which has grown up round the two species, though not for all. Some may be due to incorrect identifications and the consequent incorrect data on distribution. In view of the immense range of G. zaddachi and its recognition and acceptance as a typical salinity indicator in ecological work, it is important that the whole subject should be cleared up once for all and the present paper is an endeavour to this end.

G. zaddachi was first established as a distinct species in I9I2, when I found 
and described ten specimens of it in a collection of Crustacea taken by Herr W. Klie in the harbour of Bremerhaven. I named it after Zaddach (I844), who was the first to draw attention to its difference from $G$. locusta, although he recorded it, with a query, under that species. I was enabled, however, before publishing my description, to examine Zaddach's original specimens preserved in Königsberg Museum, and thus confirm the distinctions between the two species.

The material from several collections available to me at that time consisted of about 2000 specimens of G. zaddachi taken in many of the northern European estuaries and ranging from the fresh water at the upper end, through variations of salinity to the mouth of the river where it entered the sea.

During the course of the investigations on the species a remarkable fact came to light, viz. that the difference in habitat was correlated with a difference in the external appearance, though the structure in all the forms was identical. The animals taken at the seaward limit of their range, the typical 'saline' estuarine form, were delicate and pellucid, the chitin so thin as to be semi-transparent, with comparatively very few hairs ${ }^{1}$; in consequence they presented a more spinose appearance when compared with the hairy 'freshwater' form. The latter, living in fresh water in the upper reaches of rivers and in lakes, were more solidly built, opaque, with thicker chitin in the cuticle, and with dense clusters of long fine hairs on the appendages in addition to the spines. (For description and figures see pp. 593-602, Pls. I-II.)

In fact, on taking typical samples of the two forms from the extremes of the species range, the difference in their appearance was at first glance so great as to suggest two distinct species. Further observation, however, proved it to be entirely due to the greater development of the epidermal outgrowths (the 'sensory armature') in freshwater conditions. It must be emphasized that structurally the two forms are identical, and that it is not possible to find any point of distinction other than the increase of hairs. A further proof of their being the same species is provided by the specimens which I have called 'intermediates'. These occurred in different localities in varying salinities some with more hairs developed, some with less.

It may be said as a general rule that as the salt content of the water increases so the development of the hairs decreases. A very interesting instance of this is shown in a series of samples from the Elbe, ranging from the typical "freshwater' hairy form taken in the Hamburg Water supply, with numbers of intermediates in the early stages collected at different stations down the river, to the typical 'saline' form at the farthest seaward station in the estuary at its mouth. This distribution has since been amply confirmed in several English rivers, where good series of dredgings have been made throughout the whole length of the estuaries.

${ }^{1}$ In the general descriptions throughout the paper, the word 'hairs' is used as a comprehensive term to include all the varieties of sensory equipment such as the finest delicate hairs, and setae of all grades to strong bristles, as distinct from the spinose armature. 
The more exact methods employed by recent workers, such as Serventy, Crawford, Spooner, Reid, Goodhart, and others, give clear-cut results as to the limitations caused by tidal influence on the distribution of the common north European Gammarus, G. locusta, pulex, duebeni, and zaddachi. The importance of these species in modern ecological work lies in their use as salinity 'indicators', and naturally any confusion as to their identity would nullify the value of the results.

As has just been said there has been great confusion in the past, which unfortunately persists to the present day. One of the principal causes seems to be the perpetuation of the errors of the old records in the identification of species, through acceptance of their statements without verification; and this has naturally given rise also to errors in the records of the distribution of the species. Inaccuracies of this kind have been handed down in the synonymy of a species by one Crustacea worker after another.

It is not surprising that in the early days mistakes were made. The number of species known to science was very small, and the descriptions and figures, while definite enough to distinguish one of these from the few others, proved quite inadequate for the purpose when applied to the numbers of closely allied forms found later. These forms could easily be fitted into the generalizations of the original diagnosis of the genus, but the finer specific distinctions were not noted, specimens of different species being only too often all labelled $G$. locusta if found in the sea, or G. pulex if taken in fresh water.

G. locusta, the oldest established species of Gammarus, was given by Linnaeus as the type of his genus; later authors, following him, redescribed the species, e.g. J. C. Fabricius (I775), O. Fabricius (I780), G. Montagu (I808), H. Milne Edwards (I830), Rathke (I836), Zaddach (I844), Brandt (I85I) and many others, but as they were not all dealing with the true locusta, their accounts have added to the confusion instead of clearing it. In fact, it is impossible to-day to know with certainty which species is referred to by these early writers without having access to the original collections and examining the actual specimens described by them.

Another cause of confusion may perhaps be found in the theories formulated by certain carcinologists in their efforts to solve the species problemtheories built on very insecure foundations. An example may be given from Schellenberg (1937). The theory he puts forward seems to be that a new variety of a species may be formed directly by new modifications of its environment, and that conditions which work in the same way will produce similar changes, so that forms resembling each other are to be found living discontinuously in places far apart. ${ }^{1}$ In the case he is arguing he considers that by a lowering of the salinity G. zaddachi is produced as a brackish-water

${ }^{1}$ Schellenberg (1937, p. 514) summarizes it thus: 'Mehrere Befunde bestätigen den Einfluss der äusseren Bedingungen auf den Gammarus-Bau. Gleichartig wirkende Bedingungen haben konvergente Formen hervorgebracht, so dass übereinstimmende Formen, diskontinuierlich an weit entfernten Stellen auftreten.' 
variety of the marine $G$. locusta. He ignores the facts that the specific characters distinguishing zaddachi are as clear-cut and definite as those of locusta, and that the resemblances are simply generic. Even where the areas of their distribution overlap a little in the marine zone, zaddachi is as distinct from locusta there as it is from G. pulex in the fresh water at the other end of its range (see also p. 592).

Perhaps a further source of error may lie in the fact, pointed out to me by Prof. J. M. Pirlot (in litt., 6 February 1939), that even now another species, quite distinct but hitherto undescribed, frequenting a lower salinity than locusta, is still being mistaken for it and recorded under its name. He had described and figured it ready for publication just before the outbreak of war. Knowing how salinity conditions affect and limit the range of a species, I think it will be found later that many of the records which now puzzle ecologists, of the occurrence of locusta in unusually low salinities, can often be explained by the presence of this second species.

In the present paper I have limited my acceptance of the records of G. zaddachi to those that I could verify myself, though no doubt many others are correct in identification. There still seems to be such difficulty in recognizing the two forms of the species that I have described and figured them both in detail. The illustrations are taken from the original specimens, the 'saline' from Zaddach's collection at Königsberg, the 'freshwater' from the Hamburg water-supply pipes. They have been compared with hundreds of specimens from British rivers and estuaries and have agreed to the smallest detail. I have also noted the most striking points of difference from other species, locusta, pulex, duebeni and wilkitzkii (pp. 600-I).

I am greatly indebted to my daughter and to Dr E. J. Allen for the help I have received from them in the preparation of this paper.

\section{Historical ReVIEW}

The principal papers dealing with G. zaddachi are described below in chronological order. In tracing back the history of the species its records were found to be so involved with those of $G$. locusta from the earliest beginnings that it was impossible to extricate them without examining the specimens described. This I have been unable to do farther back than I836 (Rathke).

The first reference to G. locusta is in an account by Linnaeus (I745, p. 260) of an amphipod taken on the seashore at Gothland, and named by him Cancer macrourus coeruleus. In the Ioth edition of his Systema Naturae (1758), as also in later editions of this work, he has recorded it as C. locusta. For many years Linnaeus's work was the standard authority on the Crustacea, and the tendency of workers following him seems to have been to identify any marine Gammarus with his locusta, any freshwater one with his pulex. In an endeavour to define the specific characters with more exactitude, some of them amplified his description, e.g. J. C. Fabricius (1775, p. 4I8, under the name of Gammarus 
locusta, syn. Cancer locusta Linné); O. Fabricius (I780, No. 23I, Oniscus pulex syn. Cancer locusta of Linné); Montagu (I808, p. 92, Cancer (Gammarus) locusta); H. Milne Edwards (I830, pp. 367-9 as Gammarus ornatus, and I840, p. 44).

From certain discrepancies in their accounts it can be seen, however, that they were dealing not with one and the same species but with several different ones. Four names, Linnaeus, Fabricius, Montagu or Milne Edwards, are quoted indiscriminately by later writers as the authority for the species locusta.

I836 Rathke described as Gammarus locusta an amphipod taken by him in the Black Sea, on the eastern half of the Crimea, living on the sand and under stones where the sand was still moist. He stated that, as he had no detailed characterization of the $G$. locusta which occurred in England and France, he might be mistaken in his identification, and he would therefore give a close description. The different appendages are described with notes on their proportions, size and colour, and figures given of the 2nd gnathopod, peraeopod 5, urosome, and telson. The figures are not distinctive, but fortunately Rathke's specimens were preserved at Königsberg Museum. Two tubes of them were sent to me for examination, the one, labelled ' $G$. locusta, Krim, Rathke', contained three males of the true G. locusta (L.); the other marked 'Gammarus, Krim, Rathke' had three G. pulex in it, and one ovigerous female G. zaddachi.

I843 Rathke (pp. 67-8) in this work records G. locusta Montagu from several places on the west coast of Norway, from Christiania, and Droeback at the head of the Fjord, and from near Danzig in the Baltic. He compared them, and found no difference between them, beyond the fact that the eyes in the Danzig specimens were rather broader in relation to the length of the animals. Neither could he see any further difference when comparing them with his specimens brought back from the Black Sea, except for a greater length of the hairs on the 2nd antennae of the Crimean animals, and a slight variation in the proportionate breadth of the rami of the 3 rd uropod.

Fortunately, some of his specimens were still in Königsberg Museum, labelled 'Gammarus locusta, Montagu, Norwegen; Rathke'. I examined the fifteen preserved. They were all fine examples of G. zaddachi, the 'saline' form, 9-22 $\mathrm{mm}$. in length, males and ovigerous females.

I844 Zaddach (pp. 4-6) recorded a species of Gammarus from the Prussian coast, which he attributed, though with a query, to $G$. locusta Fabr. as described by Milne Edwards (I840, p. 44). He pointed out that his specimens differed from this account, notably in two characters, viz. the presence of clusters of long hairs on both the antennae, and the proportions of the rami of the 3 rd uropods. He stated that if Milne Edwards's characterization were accurate, then this description of his Prussian animals would constitute a new species of the genus Gammarus. It is interesting to find Zaddach had noted the two most striking distinctions between the true locusta and these specimens from the Prussian coast. He was evidently reluctant to institute a new species, perhaps because, having investigated the collection of 'the celebrated Rathke', from the Norwegian coasts, he had compared the ' $G$. locusta' represented there with his own animals and had found them identical in structure. That he was right in making this statement has just been shown above-the Norwegian specimens labelled G. locusta by Rathke were in fact all $G$. zaddachi.

I was able to examine Zaddach's collections (see Sexton, I9I2) and establish beyond doubt the distinction of the species. I therefore named it in honour of Prof. Zaddach, as he was the first to draw attention to the characters peculiar to it.

I85I Brandt (pp. 132-5), in reporting on von Middendorff's Siberian collections, found a single specimen of Gammarus from the Doschkander River which flows into the Sea 
of Okhotsk. He placed it under the Section I. A. a. of Milne Edwards (Hist. nat. d. Crust., I840) defined as having the inner ramus of the 3rd uropod as large, or at least more than half as long as, the outer: he named it $G$. locusta with a query. He would, he said, have unhesitatingly attributed it to that species (the G. locusta of O. Fabricius) but for some differences in the proportions and greater hairiness of the antennae and the shape of the uropods, and also because of lack of knowledge of the structure of the 3rd pair, which was missing.

Brandt made a great effort to clear up the confusion in the synonymy of locusta, as he had found that several obviously different species had been included under this name. He traced the history of the species from the original diagnosis of Linnaeus, and discussed the various authors who had afterwards dealt with it, Roesel, Klein, Sulzer, Herbst, Pallas, Frisch, Otto Fabricius, J. C. Fabricius, Montagu, Kröyer, Leach, Desmarest and Rathke. The three last, he said, had accepted Montagu's determination (and this is borne out by Rathke's specimens being labelled ' $G$. locusta Montagu'). He then referred to Milne Edwards's description of the species and the discrepancies between his account and those of O. Fabricius, and of Montagu. In discussing Zaddach's (1844) Gammarus from the Baltic he agreed with him that it could only doubtfully be assigned to locusta Fabr., since it showed several variations from Milne Edwards's description.

His conclusions throw little light on the subject, for they are based on the very inadequate descriptions and figures of the earlier authors, and not apparently on any of the actual specimens; but at least his work shows that by this time the need for more exact specific distinctions or definitions was clearly recognized.

I862 Spence Bate (p. 206, pl. 36, fig. 6) in the British Museum Catalogue, included under the name of 'Gammarus Locusta' all the previous records, Linnaeus, Montagu, Milne Edwards, Rathke and Zaddach amongst others. He described the rami of the 3rd uropod as 'subequal'.

r863 Bate and Westwood. On p. $378 \mathrm{G}$. locusta is figured, practically the same drawing as in the British Museum Catalogue. The description is more detailed, and an effort is apparently made to combine the conflicting statements of the previous observers, without any realization that they related to different species. For instance, it is said 'the antennae have the peduncles strongly hirsute' (i.e. like zaddachi) but the figure shows them almost glabrous (i.e. like the true locusta); and the 3 rd uropods 'have the branches subfoliaceous and nearly of one length, the inner one sometimes one-fourth or one-third smaller than the outer one' (i.e. including characters of both locusta and zaddachi).

I873 Möbius (pp. II8-I9) recorded the occurrence of G. locusta L. from thirty-four stations in the Baltic, with the depths and nature of the ground on which the amphipods were found. As references he gave Linnaeus's Syst. Nat. and Bate \& Westwood's description mentioned above. Some of these records no doubt apply to the true locusta, but that others are certainly of zaddachi I have been able to prove by examining the collection preserved at Königsberg Museum. The tubes sent to me were all labelled $G$. locusta and included several from the localities given by Möbius. One of these, marked 'Gammarus locusta L. Kiel, Möbius, 1872, No. 6526' contained three specimens, a male and two female zaddachi, $\mathrm{I}_{3}-\mathrm{I} 5 \mathrm{~mm}$. in length; two tubes from Zoppot, one also dated I872, with forty-five zaddachi (saline form); three from the station near Memel with seventeen zaddachi (saline form); and mixed dredgings from Danziger Bucht, Zoppot, Hela, etc., various depths I-25 m., I68 specimens, of which nineteen were locusta and 149 zaddachi (saline form).

I878 Zaddach (pp. 27-32) in this paper gives a full description of the species which he had previously identified as $G$. locusta Fabr. with a query, but which he now considers to be unquestionably that species. In his list of references he cites Fabricius, Spence 
Bate, and Möbius. He gives a detailed account, with numerous figures, to illustrate the structure, the reproductive organs and the differences between male and female, and between the adults and the young and the changes at the various stages of growth. Of the two distinctive specific characters which he had emphasized in I 844 he mentions the long setae on the antennae, though without drawing particular attention to them; but, in discussing the second character, viz. the proportionate length of the two rami of the 3 rd uropod, he affirms that his specimens differ definitely in this from the species character given by Spence Bate and Milne Edwards. Instead of 'the 2 rami of an almost equal length' they have the inner ramus the shorter of the two, about threequarters the length of the outer ramus in adults and even shorter in the young.

Zaddach's specimens were preserved in the Königsberg Museum collection. I have examined thirty-six of his tubes of Gammarus, thirty-two of which were labelled G. locusta. They contained 648 specimens from a large area extending from the open sea near Memel, along the Baltic coasts westward to the Gulf of Danzig and Putziger Wick, and from near the shore to a depth of $25 \mathrm{~m}$. Many rivers drain into this area, e.g. the Niemen, Pregel, Vistula, and the salinity is therefore low. It is interesting to note in confirmation of the statement previously made with regard to the range of the two species being strictly limited by the salinity that the seventy-one locusta of Zaddach's collecting were found in the higher salinity of the open sea, and the 577 zaddach $i$ saline form, in the estuarine waters.

I886 Kraepelin (pp. 13-25) gives an account of the Hamburg water-supply system, which at that date drew its water from the Elbe above Hamburg, and of the living things that were able to enter it direct from the river owing to the lack of a central filter-plant. He took many samples of the contents of the underground pipes with the idea of perhaps finding blind forms living in the darkness, or modifications of the river animals caused by their life underground. Though unsuccessful in this, he obtained no less than fifty different genera in the fauna. Amongst the Edriophthalma he mentions Asellus aquaticus in all the samples, as occurring in thousands, and second to it only in numbers 'Gammarus pulex'.

He points out that though the animals enter from the river, there is a dissimilarity between the faunas of the river and the supply pipes; that all air breathers and vegetable feeders perish in the latter, and only those survive which are provided with gills and feed on detritus. For these the conditions of life in the pipes are much more favourable than conditions in the river, the pipe fauna enjoying a much greater abundance of food, protection from its enemies, and only slight variations of temperature.

Some of this material collected by Kraepelin, and by the Director of the waterworks, was sent to me for examination. The specimens, all labelled 'Gammarus pulex', numbered seventy-nine, and were all the typical freshwater form of $G$. zaddachi, the largest measuring $20-22 \mathrm{~mm}$. in length. The illustrations of the freshwater form (Pls. I, II) were taken from one of these specimens.

1889 Hoek, ${ }^{1}$ in preparing his list of the crustacean fauna of the Netherlands, was faced with the difficulty of the conflicting records of the characters and distribution of $G$. locusta. The earlier writers had accounted for the confusion by stating that the species was an extraordinarily variable one. Hoek was able, however, to show that this was caused, not by any variability of character or habitat, but by the fact that several distinct species had been included under the one name, locusta. He made a careful study of numbers of specimens from different localities, and as a result divided them into four well-defined forms, as follows:

${ }^{1}$ My thanks are due to Mr Van de Kasteele, the Dutch Consul in Plymouth, for his kindness in translating Hoek's paper. 
(I) The 'true G. locusta', living in the sea near the coast, farther out than marinus, the typical coast form;

(2) 'Variety A', inhabiting brackish water, found by Hoek himself in the Haringvliet and other places at the mouth of the Rhine, and the Waal;

(3) 'Variety B' (=G. pulex Fabr.), from perfectly fresh water in brooks and ditches; and finally

(4) 'Variety C', another brackish form, distinct from variety A, collected by Ritzema Bos in I87I in a slightly brackish ditch near Warffum. This was later identified by Sars as ' $G$. duebeni Lilljeborg'.

All four forms are well characterized with figures of the head, pleon armature, 3 rd uropods and telson of each. I have compared Hoek's description of the characters of variety 'A', and its distinctions from locusta with G. zaddachi and found the two forms in such complete agreement (see p. 597) that there seems little doubt but that they are identical. The habitat also, with the salinity, is where one would expect the saline form of $G$. zaddachi to flourish.

Hoek found 'variety A' very common in the Haringvliet, at Hollandsch Diep above and below the bridge at Moerdyk in 4-7 fm., and at Nieuwe Merwede, where, he says, the salt content was somewhat different in these three differently named parts of the same river. The highest salinity he recorded was in the Haringvliet, $8.9 \%$ at $6^{\circ} \mathrm{C}$., though usually it is here much lower, from 3 to $3.2 \%$. In the other places named it varied from about $\mathrm{I}-0 \%$. He was unable to extend his investigation farther up the river, though he considered it probable that such animals might exist there, and that it would be very important to ascertain to which variety they belonged.

1890 Sars (p. 499, pl. I and pl. I76, fig. I) describes the true G. locusta of Linnaeus, figuring

to it as the type of an amphipod. He was the first to give an accurate representation of the

' 1894 whole of its structure. He identifies Hoek's 'variety B' with G. pulex, and 'variety C' with G. duebeni.

1893 Dahl (p. 168) records G. locusta as one of the commonest animals in the Elbe from Hamburg down to the North Sea, and of special importance as food for fish. He adds that the species is very plentiful in the Lower Elbe in spring, practically absent in autumn, giving as an explanation of this fluctuation in numbers the statement that $G$. locusta during the summer lives on the shore under stones and among mussels (Mytilus) attached to woodwork and goes in winter into deep water. The animals at Hamburg, he says, live in quite fresh water with another species, G. pulex L., recorded by Kraepelin. He considered locusta and pulex to be very closely related, and thought it probable the 'freshwater locusta' might prove to be a form transitional between the two. He therefore examined specimens from the sea, and some from Altona, taking as distinguishing characters the eyes and the two rami of the 3 rd uropods but no such transitional characters could be recognized. Kraepelin showed him some of his material from the Hamburg water system which he had identified as G. pulex L. In Dahl's opinion the specimens were definitely G. locusta, and he adds that Kraepelin naturally did not expect these sea forms in fresh water, and therefore had paid no attention to the small differences which distinguish them. It has already been shown (p. 58I) that Kraepelin's specimens from Hamburg were G. zaddachi.

1892 Chevreux et Guerne. The two papers given in the bibliography were published at the same time, May 1892, and contain practically the same matter, viz. a description of a new species of Gammarus from Lake Annecy and a review of the freshwater Gammarus of France. The account in the Bull. Soc. Zool. is the more detailed, and contains figures for a comparison of the new species with $G$. pulex.

The authors mention ' $G$. locusta Linn.' as a marine form, able to adapt itself to life in quite fresh water. They state (p. I4I) that it is 'extrêmement commun dans la Loire, en amont de Nantes à plus de 80 kilomètres de la mer et se trouve aussi dans les 
rivières de la Corse et de la Provence, au voisinage de l'embouchure'. They consider that $G$. locusta has frequently been mistaken for $G$. pulex in similar conditions, and cite, in corroboration of this, Dahl's statement that the Gammarus of the Hamburg water supply, identified by Kraepelin as $G$. pulex, was in reality G. locusta 'ayant remonté l'Elbe'.

I899 Chevreux revised the list of the Amphipoda found on the oceanic coasts of France. It is interesting to note that he now separates the Gammarus of the Loire from locusta under the name of ' $G$. Duebeni Lillj.', while giving the same locality 'au bord de la Loire, depuis Saint-Nazaire jusqu'en amont de Nantes'. The second locality mentioned, 'Prairie de Mauves', is on the river near Nantes.

But Chevreux was evidently not satisfied with his identification of the species, for after the publication of my paper in which I said that these animals were probably G. zaddachi (I9I2, p. 66I), he sent me specimens from his collecting in the district, labelled ' $G$. Duebeni Lillj.' and asked me to examine them and confirm the identification, if correct. Some were from 'Nantes, au bord de la Loire', some from 'Belle Ile-en-Loire (eau douce)', but all, without exception, proved to be G. zaddachi.

1907 Volk gives an account of an investigation in the lower reaches of the Elbe on the effect of the sewage water from the towns of Hamburg, Altona and Wandsbek on the fauna and flora of the river. The area surveyed extended from the freshwater region of Gauert, I $5 \mathrm{~km}$. from the harbour of Hamburg and far above any contamination from the city drainage, down to the Third Lightship and Neuwerk Island in the estuary of the Elbe where, with high tide and the wind inshore, nearly the full salinity of the North Sea water is encountered. A chart of the district surveyed shows the tributary streams, canals and docks at Hamburg and Altona. Detailed descriptions are given of the different harbour basins, the nature of the ground, and the plant life found in them. Temperature, chemical analyses of the water, the biological collections and their quantitative distribution are also reported on.

Volk records the occurrence of 'Gammarus pulex' in Altona Harbour, where the river receives the sewage of that town, and where it contains the typical fauna and flora found in sewage-polluted water having a low oxygen concentration. He states that, though an animal usually sensitive to contamination, it occurs here in surprising quantities. In view of the fact that the River Elbe receives the sewage of Hamburg also, the outfall being about $2 \mathrm{~km}$. above Altona, he regards this occurrence of 'Gammarus pulex' as supporting one of the general conclusions of his survey of the river which he expresses thus: ' 'on the whole the biological relations are such that there can be no question whatever of a pollution of the Lower Elbe harmful to the fisheries, in consequence of the inflow of sewage from Hamburg, Altona, and Wandsbek.'

The 'Gammarus pulex' collected at twenty-one stations in this Survey were sent to me for examination; all the specimens, 564 in number, proved without exception to be $G$. zaddachi, both forms, the freshwater and the saline, being represented.

I9II Vanhöffen (pp. 399-405) describes a collecting trip made by him in September I9I I to Pillau on the Frisches Haff for the purpose of obtaining specimens of the brackish water coelenterate Cordylophora lacustris Allm., the so-called 'prickly moss' of the fishermen. It forms dense masses in the eastern part of the Haff, where the water still has $I \%$ salinity. Vanhöffen found it growing plentifully in the 'Graben' (or Moat) which runs in from the Haff at Pillau, separating the old port from the new part of the town, and ending inland.

1 'Alles in allem liegen die biologischen Verhältnisse so, dass von einer die Fischerei schädigenden Verunreinigung der Unterelbe durch die Sielergüsse von Hamburg, Altona und Wandsbek überhaupt keine Rede sein kann' (p. 54). 
On preserving the material from the Graben, he found a rich animal life in the sediment, comprising no less than forty species, showing an interesting mixture of marine, brackish and freshwater forms, of which thirty were new records for the Frisches Haff. Amongst these thirty, he gives 'Gammarus locusta L.', but says the specimens found were all young, judging by the small number of joints, four in the accessory flagella of the Ist antennae.

Vanhöffen sent me twenty-four of these specimens labelled 'Gammarus locusta L.' On examination they proved to be all G. zaddachi, the saline form, measuring from 2 to $10 \mathrm{~mm}$., the largest, strongly built and opaque, approaching the freshwater type.

I9I2 Sexton (pp. 656-65, 2 pl.). Some estuarine amphipods, taken by Klie (1913) in the old harbour at Bremerhaven, form the subject of this report. Amongst them were ten small specimens of a Gammarus new to science which I described as G. zaddachi n.sp. The largest specimen, a female $9 \mathrm{~mm}$. long, was figured. I compared the animals with an estuarine form collected in the River Tamar at Plymouth in I9II, and with some specimens, labelled G. duebeni, from the Norman Collection in the British Museum from Suffolk, East Anglia, and found they were one and all the same species. The report was prepared, but just as it went to press, a great quantity of material became available, including, amongst others, Vanhöffen's collection from the Frisches Haff, and the estuary of the Oder; Zaddach's from Königsberg Museum (dealt with in a separate paper(I9I3)); and, in particular, the interesting series of samples referred to above under Kraepelin and Volk. In the reconstruction of the paper, the English samples were, through some oversight, omitted.

While this varied material was being investigated, the remarkable difference in the appearance of the animals was noted, and correlated with the conditions in which they lived. Those from fresh water had thick chitin in the cuticle, and long fine hairs conspicuously developed; those from brackish water, the 'saline form', were spinose with few hairs, and a thin semi-transparent cuticle. The figures illustrating the new species were taken from the latter form, the female being illustrated in this I9I2 paper and the male in the next (1913). But, as so far only the 'saline' has been represented, and as so many observers have failed to recognize its identity of structure with the 'freshwater' form, I have figured both forms in detail in the present paper.

I9I3 Sexton (pp. 90-4, I pl.). An account is given here of the collection of Gammarus in the Königsberg Museum, with figures of the males of G. locusta (L.) and pulex (L.) for comparison with the male of zaddachi. Specimens of the true locusta and pulex from British collections and of duebeni sent by Prof. Sars were compared with the new species and the differences noted.

Some errors in the printing of the text and plate will be seen (e.g. two joints instead of three in the peduncle of the first antenna of $G$. locusta) which could have been avoided had the usual practice been followed of sending the proofs for correction.

I9I3 Klie here describes his study of the seasonal distribution of the crustacean fauna of the Old Harbour of Bremerhaven. He took a series of samples at regular intervals during the year March I9I I to March I9I2, noting also the tides, salinity and temperatures. The water surface of the Old Harbour he says is only $7 \cdot 2$ hectares, with a depth at mean high water of $7.06 \mathrm{~m}$. Its situation at the mouth of the Geeste, where the stream of the Weser meets it almost at right angles at the entrance, together with the narrow sluice entrance, II m., accounts for the relatively low average salinity of the water, $5 \%$. This is subject to constant variation, since the flushing water of the sluice at each tide causes a variation of the water level in the harbour and basin of I $\mathrm{m}$. or more, a change which becomes very obvious through the predominance of fresh water at the ebb, and through the entrance of sea water at the flood. An increase of salinity in the height of summer each year has been recorded, as also a decrease in autumn and winter, the explanation given of this phenomenon being the lowered freshwater inflow, and 
the evaporation during summer. Klie quotes figures to show the variation: e.g. on 22 October I9IO the salinity was $3.35 \%$, on the same date in I9II it was $8.13 \%$; on 18 December I9IO it was $\mathrm{I} \cdot 80 \%$, the corresponding value for the same date in I9I I being $6.32 \%$. In the table of salinities he shows the range of the variation for one year, the lowest record being for March, 0.79 and $\mathrm{I} \cdot 02 \%$, temp. $7.2^{\circ}$ and $7 . \mathrm{I}^{\circ}$ at low tide; and the highest in September, $12.64 \%$, temperature $17.6^{\circ}$, also taken at low tide. It is in conditions such as these that $G$. zaddachi flourishes, as has been observed many times, and Klie records its appearance in twelve samples, and states that it is very common and to be found in the same places throughout the year.

I9I5 Tesch (pp. 336-9), in his account of the Amphipoda collected by the 'Wodan' in the southern area of the North Sea, discusses at length two specimens, male and female, of a species of Gammarus from the open sea, which he could not identify with any of the known species. He refers to Hoek's work on $G$. locusta (see p. 58I), in which he showed that the idea of the so-called 'variability' of the species was due to the inclusion of several different species under the one name, the 'true locusta' was not variabie.

Tesch gives a very careful comparison of his two specimens (male $17 \mathrm{~mm}$., female I5 mm.), with both the 'true' locusta and Hoek's 'locusta, variety A', and shows that they agree with 'variety A' much more than with the typical form, in the following characters, viz. the proportions and the number of joints of the antennae in both sexes; the armature of the pleon segments $4-6$, which differ from the typical form in not being produced dorsally in definite humps; the telson; the 3 rd pair of uropods; and the proportionate length of the two rami, with their spines and hairs. Indeed, he says, that were it not for the inexplicable fact that the label of his tube of specimens gives the position of the place of capture as the open sea (St. H. 4 b., about ro miles from the coast, and over a depth of $80 \mathrm{~m}$.) and also for the knowledge that 'variety A' is recognized as a purely brackish-water form, he would unhesitatingly identify them with that form. $\mathrm{He}$ considers them quite distinct from locusta and therefore meriting a separate name.

I916 Stephensen (pp. 236-7, and 293) records G. zaddachi Sexton as new for Greenland, one specimen being taken in I9I2 in a freshwater stream at Narssak Skovfjord, south Greenland. He says the specimen was small, $7 \mathrm{~mm}$. long, and a little defective, but that the 3 rd uropod and 4th sideplate were in excellent accordance with Sexton's figure.

\section{I9I 7 Stephensen (pp. 37-50, figs. I-5) and}

I9I8 Stephensen \& Ussing (pp. 335-8, figs. $9 a, b$ ). The Gammarus discussed in these papers were captured in Randers Fjord, Denmark, during an investigation undertaken with the particular object of seeing to what extent the variation in salinity influenced the fauna. The salinity range was from fresh water $0 \%$ at the head of the fjord, to $24 \%$ (bottom) and I $8 \%$ (surface) at the mouth. Stephensen records five species of Gammarus, viz. G. pulex L., G. locusta L., G. zaddachi Sexton, an intermediate form between locusta and zaddachi, and G. duebeni Lillj.; but, he states, the specific characters are so vague that it is most probable that all the species he mentions are in reality only one species (1917, p. 37).

G. locusta L. was taken only at the mouth of the fjord in $16-24 \%$ salinity, but, in discussing its distinctive characters in order to illustrate how greatly the species can vary with the environment Stephensen described specimens of 'locusta' from different parts of the world, from Spitzbergen, the Kara Sea, Greenland, Arctic Seas, Great Britain and east America. (The figure given, however, of a male 'locusta' from the Kara Sea (I9I7, p. 40, fig. 3) is evidently the Arctic species G. wilkitzkii Birula (see Gurjanova, 1930, p. 588).)

Most of the specimens identified as zaddachi and an 'intermediate form' were taken in water of lower salinity. Stephensen, also, refers to Hoek's work on locusta and its varieties (1889), and unites zaddachi with Hoek's 'variety A', saying, however, that he 
considers it is not a true species but only the brackish-water form of locusta, and that the forms merge into each other.

Later on he re-examined this collection (see 1927, p. 120) and attributed all the specimens to $G$. locusta, acknowledging $G$. zaddachi as a distinct species.

1922 Schäferna (p. 96, text-fig. 6), in describing new freshwater species of Gammarus from rivers, brooks and pumps in the Balkan peninsula, names one, G. spinicaudatus, as near to zaddachi. He apparently accepts Stephensen's view (I9I7) that zaddachi is a variety of locusta, and says that his new species also is connected with locusta 'but more progressed than the G. zaddachi form'. There are not, however, sufficient distinctive characters given in the summary or in the figures to enable one to judge of the correctness of his view.

I922 Schlienz (p. 215) says that in studying the Gammarus of the Lower Elbe he found a difficulty in obtaining dependable characters on which to separate the species. $\mathrm{He}$ quotes Stephensen (I9I7) as having had the same difficulty, especially in distinguishing between locusta and zaddachi, and as having eventually reached the conclusion that the brackish-water zaddachi described by Sexton was only a variety of locusta. Schlienz goes on to state that, in his opinion, Sars's description and figures of G. campylops Leach, Sexton's species zaddachi, and his own material from the Elbe, all deal with one and the same animal, and that the one established by Leach in I813-r4.

It may be well to note here that Sars's identification of his species with Leach's campylops was an error. This, indeed, can be seen by comparing his figures, especially that of the 3 rd uropod (1890, pl. I76, fig. 2), with Spence Bate's drawing of the same appendage from Leach's type specimen in the British Museum (1862, pl. 37, fig. 3), which was confirmed by Walker (I9II) and Calman. They pointed out that Leach's types had the unmistakable short inner ramus characteristic of G. marinus and that Sars's animals belonged to a different species and were probably some young specimens of locusta. It is curious that Schlienz did not see this himself. He had the reference to Spence Bate in Sars's description, and also all the specimens of G. zaddachi which I had identified, in Hamburg Museum, where he could have studied them. Later, when Walker's paper came into his hands, he argued that Sars must have had a brackish-water form of locusta before him which was evidently zaddachi; that Leach's 'campylops' became a nomen nudum, but the name could be retained for Sars's species; that zaddachi as a name must drop out, and the species should have only varietal status, and be known in future as 'Gammarus locusta Linn. var. G. campylops Sars'. This matter has been dealt with here rather fully, and also in Sexton \& Spooner (I940, pp. 673-5), because it is one of those mistakes in systematic work which get carried on indefinitely in the history of a species and cause so much waste of time in refuting them.

I923 Schlienz (pp. 429-52) in this paper gives an account of the conditions in the Elbe Estuary, such as salinity, nature of the substratum, sewage water, etc., as they affect the higher Crustacea.

Collections were made at twenty-six stations from Lauenberg, $570 \mathrm{~km}$. from the river source to Cuxhaven on the Estuary, $725 \mathrm{~km}$. Three species of Gammarus are recorded, G. locusta (L.), G. duebeni Lillj., and G. zaddachi Sexton, referred to throughout as G. locusta Linn. var. campylops G. O. Sars. The latter species was taken at all the stations in the area investigated, even up to the main sewer. Far from avoiding polluted waters, it occurs in almost incredible numbers below the actual harbour region of Hamburg, and is especially numerous near Mühlenberg (Blankanese), and at the Estemündung, where suitable places of refuge are afforded by the fresh and brackishwater hydroid Cordylophora lacustris and the two pond weeds Potamogeton perfoliatus and $P$. pectinatus. A table of salinities shows the occurrence of Gammarus zaddachi in brackish water, $0.5-18.0 \%$, with the lowest mean salinity as $0.37 \%$; of duebeni from 
4.40 to $18 \%$; and of locusta, mean salinity $18-32 \%$, lowest $13.15 \%$. Schlienz concludes that, while this species cannot be regarded as an indicator (Leitorganismus) for the impurity of the region in question, it still follows that, as it exists in such great numbers, it is an essential member of the living community of the mesosaprophytic zone and a considerable factor in the biological self-purification of the Elbe.

1926 Szidat (p. 9) enumerates the many rivers draining into the Kurisches Haff, to show the great inflow of fresh water. That the salinity of the mesohaline region is very low, he says, is demonstrated by the presence of $G$. zaddachi and Cordylophora lacustris on the Mole at Schwarzort, together with numerous freshwater forms. In his list of Amphipoda (p. I5) he gives 'Gammarus zaddachi (Sexton) = G. locusta var. campylops (G. O. Sars)', as found in both the mesohaline and polyhaline regions, and as occurring abundantly at Memel.

I926 Riech (p. 36) gives practically the same range of salinity for zaddachi in the Frisches Haff. He states that it is extraordinarily numerous in the algal growth, with Cordylophora lacustris 'die Leitform des Brackwassers'; and that it is found in all the littoral of the mesohaline region, as well as at Pillau and other places in the polyhaline division.

1927 Stephensen (p. 120), in his revision of the Danish Amphipoda, acknowledges Gammarus zaddachi Sexton as a distinct species. He says it has never yet been taken in Denmark, and that the specimens from Randers Fjord, which he ascribed to it in I9I 7 (p. 4I), proved on re-examination to belong without a doubt to locusta.

I928 Sexton describes a series of experiments, the aim of which was to ascertain whether or not cross-breeding could take place between closely allied species of the same genus, and, in particular, between species living in the same environment. For several years previously the material for these experiments had been in course of preparation.

Beginning in I9I2 with the brackish $G$. chevreuxi it was discovered that this species was able to adapt itself to great changes of salinity and could be brought to live in any conditions from perfectly fresh water to supersaturated sea water, provided only that the change over was made gradually and sufficient time allowed for the animals to accommodate themselves to the successive increases or decreases of salinity. It was found that more time had to be allowed for the last stage-the decrease to fresh water.

Eventually six species were used, viz. G. locusta, marine; G. duebeni and chevreuxi, brackish; G. pulex fresh water; Marinogammarus marinus, marine littoral; and $M$. stoerensis brackish. Three stocks of each were kept going, in fresh water, in brackish and in full sea water, and throughout the work, carried on for several years through many generations, special attention was given to note what effect, if any, the changes might produce on the specific characters. The most striking point to emerge from these observations was the inherent constancy of the specific types. The species characters, far from being variable, were not affected in any degree by changes of temperature, salinity, food, or other conditions; growth stages could be accelerated or retarded without affecting the structure in any way; young hatched after a Io-day incubation compared with those which had taken I2O days showed no differences; and specimens brought in from the wild were identical in appearance and mated at once with those of the same species inbred in the laboratory for several generations. The characters remained stable, and were transmitted to their offspring without modification.

It was important first of all to establish the fact of this constancy of type, for in systematic work where there has always been difficulty in distinguishing between the young and immature of allied species of a genus, the suggestion has frequently been put forward that these forms might be varieties due to chance interbreeding. It was necessary therefore to investigate this question, and as some hundreds of animals were available in all the stocks, fresh, brackish and marine, a large number of reciprocal crosses were set out.

To sum up briefly: no results were obtained from any combination of locusta, duebeni and marinus with the other species, no matings took place, and in most of the 
crosses the females were eaten. Out of fifty-seven animals male pulex $\times$ female chevreuxi, five matings were recorded, no eggs laid; in the reciprocal cross, out of I48 animals, fifteen females paired and five batches of eggs were deposited, all infertile. Out of 39I animals, male stoerensis $\times$ female chevreuxi, there were only two pairings, no eggs, and most of the females eaten; in the reciprocal cross, 468 animals, twenty-nine pairings took place, eight batches of eggs were laid, all infertile. With twenty-one animals, male stoerensis $\times$ female pulex, there were five pairings, no eggs, all the females eaten; in the reciprocal cross the results were the same.

These results show that even in the most favourable and carefully prepared conditions, with each pair accustomed to the same salinity, guarded from outside attack, and provided with a plentiful supply of food, not a single cross-bred young was produced. None of the eggs laid developed, but were discarded by the females before the end of the incubatory period.

1928 Stephensen (pp. 275-8, fig. 58), in a key to the genus Gammarus, reinstates G. zaddachi as a species. For the principal character distinguishing it from G. locusta he takes the 4th sideplate; in locusta much deeper than broad, lower portion almost rectangular, corners rounded; in zaddachi not deeper than broad, inferior margin almost semicircular. Other distinguishing characters given by him are: peduncle of antenna I longer in proportion than in any other known species of Gammarus, and thickly beset with clusters of setae graduated in length; dorsal humps not very distinct; and inner ramus of uropod 3 only about three-quarters as long as outer.

He states that the species has not yet been found in Denmark and gives its distribution as recorded in Sexton (I9I2, I9I3).

I929 Stephensen (pp. 138-9; text-fig. 34-figs. 24I-2). This is the same account of Gammarus with the key and the characters distinguishing zaddachi from locusta, as that already given in I928. He adds a reference to the occurrence of zaddachi in the Frisches Haff (where it is known as the 'Krabbenplage'), in such masses as to injure the fishing nets.

1930 Gurjanova (pp. 24I-4, fig. 9) gives a redefinition and figures of G. wilkitzkii (Birula), one specimen of which had been taken in Ob-Jenissei Bay and described by Birula in 1897 as a variety of $G$. duebeni Lilj. Stephensen (1917, fig. 3) figured it as G. locusta L., and later it was suggested as the Arctic form of G. zaddachi. Gurjanova here distinguishes it as an independent species, and points out the characters in which it differs from other northern Gammarus, e.g. the shape of the head with very deep sinus; the eyes broadly reniform, relatively shorter and broader than in the other species; the numerous clusters of long hairs on the lower margins of both antennae; the shape of the gnathopod hands; and the rami of the 3 rd uropods almost equal, and beset on both sides with long feathered bristles. She gives the known distribution of the species, Ob-Jenissei Bay, Nordenskiöld Sea, and Stephensen's specimen from the Kara Sea. It inhabits seas of very low salinities, and reaches a great size, up to $48 \mathrm{~mm}$. Gurjanova collected G. zaddachi in large numbers in the White Sea, at the mouth of the Sewernaja Dvina, in quite fresh water. The salinity in the estuary during flood-tide does not exceed $7-10 \%$ and falls during the ebb to $0 \%$. She considers that G. zaddachi and other organisms (such as Anurea cruciformis, Zostera, etc.), which are common in both the Baltic and the White Sea in the river mouths, are relict forms indicating that formerly an interchange of the faunas of these seas must have taken place.

Dr Stephensen kindly sent me three male specimens of Gammarus wilkitzkii from east Greenland, $6 \frac{1}{2}^{\circ} \mathrm{N}$., $33^{\circ} \mathrm{W}$., measuring respectively 30,44 and $45 \mathrm{~mm}$. It has been suggested that this species is the Arctic form of zaddachi, and certainly the dense clusters of setae on the antennal peduncles give a superficial resemblance; but the points of difference are well marked, and confirm Gurjanova's view that it is a quite independent species. It can be easily distinguished from zaddachi, by its strongly 
built body, small head and eye, and by its appendages which are all longer and more slender in proportion, with the hair clusters denser and more numerous on the anterior portion of the body, less so on the posterior.

1933 Gurjanova (pp. 75-90), in a list of the Crustacea found in the mouths of several of the great northern rivers, in the Baltic, and in the Caspian Sea, again states that the fauna of the Northern Dwina (Sewernaja Dvina) mouth is nearer to that of the Baltic than to the fauna of the Siberian estuaries. The fact that Mesidotea entomon entomon and Gammarus zaddachi occur only in these two localities points to a former connexion between the Baltic and the White seas.

I932 Poulsen (pp. I-I2, figs. I-5), when examining the invertebrates collected by the Danish Commission for Research of Sea and Fisheries, found a number of specimens of Gammarus in the material, captured in the waters between the Islands of Sealand, Möen, and Falster. To complete this material, collections were made in quite shallow water along the coasts.

Between the islands, the depth of the water does not usually exceed 3-4 m. and the salinity is low, generally varying between 7 and $10 \%$, only exceptionally reaching $\mathrm{I} 2-13 \%$.

Three species of the genus were taken: G. locusta L. in great numbers all over the area; G. duebeni Liljeborg, well represented in the material; and G. zaddachi Sexton, found in only two localities, Stege Nor, Möen, and at Gaabense, Falster. Poulsen gives detailed descriptions of all three species, together with measurements, and figures. For the most characteristic features by which the three species can be quickly distinguished from each other, he gives: for locusta, the Ist joint of the Ist antenna carrying on its underside only one hair besides the distal cluster of hairs, and secondly, the distinct nodular projections on the three urosome segments: for duebeni, the numerous hairs on the dorsal part of the urosome; and for zaddachi the length of the peduncle of the Ist antenna, and the clusters of hairs on its underside; and the 'nonhairy dorsal parts of the Ist-3rd urosome segments'.

The characters hold good for comparison with the true locusta, but not for duebeni, since we now know that the freshwater form of zaddachi has as many if not more hairs dorsally; and similarly, not for zaddachi since both forms carry hairs as well as spines on the urosome and the description 'non-hairy dorsal parts' refers only to the most extreme development of the saline form. Poulsen evidently knew nothing of the difference in the development of the specific sensory armature in relation to the difference in environment (see also Crawford, 1937, p. 660).

1933 Oldevig (p. I99) includes G. zaddachi in his survey of Sweden's Amphipoda, for although, he says, it has not yet been taken in Swedish waters, it may probably be found there judging by the records of its occurrence near the southern coast of Norway. He gives its distinguishing characters and distribution, as noted by Stephensen (I928).

1933 Palmer (pp. 64-7) found G. zaddachi in large numbers, together with G. duebeni, in a shallow brackish-water dyke behind the sea wall at Tollesbury, Essex. They were all, as would be expected, of the saline form. The colour of the living animal is given as transparent yellowish green, varying a little in intensity, with bands of brown on the posterior margins of the body segments, antennae, peraeopods, and uropods; the oil globules on the sides of the pleon are dark purplish red. The eyes are normally black with white interommatidial pigment, but five instances out of the normal were seen among the five to six hundred specimens examined; in one, a female, the pigment was red not black, and four others had 'mosaic' eyes, i.e. some of the ommatidia red, some black, the first record of such an abnormality in the wild.

1933 Bassindale (pp. 297-8, 2 figs.) discovered G. zaddachi in the Tay Estuary during the investigations of the Water Pollution Research Board. Collections were made from 
the Bridge of Earn, 32 miles from the sea, near the limit of tidal waters down to Newburgh below the confluence of the Rivers Earn and Tay. The water is for the most part fresh, the salinity at Newburgh, the lowest station at which zaddachi was taken, at high tide reached only $3-4 \%$. I99 specimens were taken, and were sent to me for identification; I98 were G. zaddachi, the typical freshwater form; four of the specimens had abnormal eyes, described in detail in the paper. It is curious that two reports on abnormalities in the wild should appear in the same year, this one on irregularities of eye-structure, and Palmer's, referred to above, on irregularities of the pigment.

1934 Schellenberg (pp. 7-I3; 2 text-figs.), in his report of the Amphipoda of the Baltic, gives for the genus Gammarus two well-defined species, the euryhaline G. locusta (L.) and the brackish-water $G$. duebeni Lilj., with G. zaddachi Sexton named as a brackishwater variety of locusta.

He discusses first the distinction between locusta and duebeni. Stephensen (1929) had characterized the latter by the numerous setae on the urosome, telson, and peraeopods. This, Schellenberg points out, is not a sufficient guide, and he adds the salient distinguishing character found in the hinder peraeopods, viz. the posterior angle of the basal joint-free in all three in duebeni, but only in the 3 rd peraeopod in locusta; that, together with differences in the male gnathopod hands, marks them as separate species. $\mathrm{He}$ comes to the conclusion that duebeni is sharply separated from the other two species although it has been frequently confused with zaddachi. All the certain records of its occurrence are concerned with brackish water of several per mille salinity, and he therefore suspects that wherever 'duebeni' is recorded in fresh water, it is really zaddachi that is in question.

His next argument that zaddachi has no standing as an independent species, but is only the brackish-water form of locusta, is difficult to follow. He does not appear always to recognize the differences between the two forms of zaddachi, freshwater and saline, nor the distinction between them and locusta, and while it seems evident that he has seen these various forms, I am inclined to doubt if all his material of locusta is of the typical true species, or in fact if some of it may not belong to Pirlot's 'low-salinity' 'voisine de locusta' type (p. 578). This view would appear to be supported by his statements (on pp. 9, 10), where, in comparing the two species, he fails to note the differences in the shape of the 4 th sideplate, and other distinctive characters such as the gnathopod hands, the development and position of the setae clusters and spines, the proportions of the rami of the 3 rd uropods, etc. The most obvious distinguishing specific character to which I drew attention (I9I3, p. 9I) he disregards, although it is an infallible guide in all the growth stages as well as in the adult animal. It is as follows: 'in G. zaddachi, the peduncles and flagella of both antennae carry dense clusters of long, graduated, outstanding setae: while in G. locusta, the upper antenna is, as in G. pulex, almost glabrous.' I have given figures (P1. I fig. I; P1. III, fig. I9) of this character, and of the gnathopod hands of the males of the two species which should suffice to show their distinction.

Another definitive character given by me (I9I2, p. 662), viz. the greater length of the antennal peduncle in zaddachi as compared with locusta, Schellenberg considers as of no use for the purpose, and quotes in support of his argument the incorrect figure, of a two-jointed antennal peduncle, from my I9I3 paper (pl. iv, fig. 3) but, as stated above (p. 584), I was not responsible for this absurd error in the reproduction of my drawing.

In his discussion of the distribution and salinity range of the two species he says there is overlapping, but locusta he rightly regards as marine and zaddachi as typically estuarine. He notes that zaddachi flourishes in the violent fluctuations of salinity such as occur in river mouths, and that it also lives well in waters of almost constant but quite low salinity, e.g. up the Elbe around Hamburg. 
Finally, Schellenberg mentions various authors and their identifications, and concludes that the following, amongst others, all refer to zaddachi: Hoek (I889) ' $G$. locusta, variety A'; Hellen (I9I9) 'G. duebeni'; Schlienz (I922), 'G. locusta Linn. var. G. campylops (Sars)'; Szidat (1926), 'zaddachi Sexton $=G$. locusta var. campylops (G. O. Sars)': and Neuhaus (I933), 'G. duebeni'.

1934 Serventy (p. 203), in his account of the marine invertebrate fauna of Scolt Head Island, Norfolk, records three Gammarus; locusta from the lower tidal levels, a member of the Zostera community: marinus from the upper levels, amongst Fucus: and zaddachi, always under estuarine conditions, widely distributed on the east coast.

1935 Serventy (pp. 286-94), in his observations on Gammarus zaddachi, gives notes on its occurrence in the River Deben in Suffolk, and its relation to the other species of the district. A diagram shows the salinity of the I2-mile long estuary, and the zones of distribution of the three principal species: $G$. locusta, inhabiting the lower part and extending to the sea outside, is the dominant form only as far as the salinity remains above $25-30 \%$. G. zaddachi occupies the zone of decreasing salinity to the limits of the tidal influence, a distance of 5 miles. The river is very small compared with the size of the estuary, and this zone is characterized not only by a very rapid fall in the salinity gradient but also by a great fluctuation in salinity between high and low water, in one place reaching $15 \%$. So that here twice daily the salinity oscillates over a range of $15 \%$; an area, therefore, as Serventy points out, of peculiar rigour for marine animals, and one 'that demands a special physiological constitution, including the development to a high degree of osmo-regulatory mechanisms in its denizens'. The third species, G. pulex, takes the place of zaddachi just above the limit of saline influence in the estuary.

Serventy examined a collection made by Gurney in East Anglia, in which zaddachi was found plentifully represented, the specimens identified by Gurney being correctly named, those by Norman wrongly called 'duebeni' (see also Sexton, I9I2, p. 584).

Another interesting investigation was carried out by him in the Tamar, where Percival (I929, p. 93) had recorded ' $G$. locusta' as occurring along the whole length of the river, from the sea to practically fresh water $(0.1 \%$ at high tide). As none of Percival's animals had been preserved, these statements could not be checked with the actual specimens themselves. Serventy therefore decided to collect in the brackish water section of the river where Percival had recorded locusta, but where, from his figures of the salinity, that species certainly could not have been expected to occur, though zaddachi might have been. From these localities he obtained zaddachi only, and there was no sign of locusta. Through his kindness in showing me his collection I was able to confirm the identification.

I936 Crawford (p. I02) refers to G. zaddachi as the commonest brackish-water Gammarus in the River Tamar and its confluents, the Tavy and Lynher, and as occurring in every stream running into these rivers. His list of localities completes Serventy's (1935) account of the distribution of the species in the Tamar.

1937 Crawford (pp. 647-62), in a more extended report on the estuarine fauna of the west of England and south Wales, names six species of Gammarus as inhabiting these regions, viz. marinus Leach, and locusta (L.) marine, the former found at a higher tidal level among Fucus; chevreuxi Sexton, duebeni Liljeborg, and zaddachi Sexton, in the brackish-water zone, though penetrating on occasions into the fresh water; and pulex (L.) fresh water.

Crawford describes the conditions and plant life of the various rivers investigated and gives the most important published lists of the British brackish-water Crustacea, together with certain suggested corrections of their nomenclature. 
I937 Schellenberg (p. 482), in the course of his remarks on the systematics of the freshwater Gammarus, raises the problem of the cause of the numbers of different forms which yet are genetically close to each other. He asks, are we dealing with differences due to environment of such a kind that particular environments transform in a definite direction the Gammarus stocks which occur there? He considers the question could be answered either by experiment or through investigations as to whether with the transition from one environment to the other, one form of Gammarus is also transformed into the other, or whether particular forms are specially adapted for particular environments. He states, though without advancing proof, that such a step-by-step transition is seen in the case of the marine $G$. locusta going over into the estuarine zaddachi, and that it is most likely the gradual freshening of the waters of the river mouths which brings about the increased bristling (see Sexton, p. 587).

Schellenberg definitely concludes that environmental conditions are able to influence markedly the structure of animals, and that conditions working in the same way have developed forms similar to each other living discontinuously at places far apart.

1937 Höf ken (pp. II6-48, 6 text-figs. and 20 tables), noting the conclusions reached by Schellenberg (1934), has attacked the problem of the Baltic species of Gammarus (G. locusta, duebeni and zaddachi) first by a statistical-variation research on a series of natural populations, and, secondly, by rearing the animals under changed environmental conditions, particularly changed salt concentrations, so as to follow up how far the development of the bristles would be influenced thereby.

He took his 'populations' from eleven places of varying salinities: from the North Sea at West Helgoland, with a salinity of about $32 \%$; Kiel Harbour, of about $17 \%$; Wittower Fähre on Rügen, $7 \cdot 2 \%$; to Neukuhren on the Samland coast with a mean salinity of $6.5 \%$. He collected also at several places in the Schlei Estuary on a fluctuating range from 18 to $3.6 \%$, and finally from Barther Bodden at Zingst. The Zingst station differed from the others in having a fairly constant salinity, of $6 \%$, and being connected with other ponds (Bodden) and the open sea only by small channels, it is cut off from the Baltic, and the interchange of water, in consequence, is slight.

In order to carry out the statistical research on the setae numbers, three characters were taken from the anterior, middle and posterior parts of the body, viz. the number of seta clusters on the 2nd joint of the peduncle of antenna $I$; the number of setae in the anterior distal cluster on joint 4 of peraeopod 5 ('Pp. 7', in Höfken's numbering of the appendages); the number of spines and the number of setae on the telson; and the size of the gill on peraeopod 5 (='Pp. 7'). The whole material was divided into size groups, each I mm. apart; one size-group, e.g. Io mm., included animals measuring IO-IO.9 mm., the next II-II.9 mm., and so on. The measurements were taken by stretching the animal on a millimetre scale, and counting from the tip of the head to the insertion of the telson. ${ }^{1}$

1 To my mind, an arbitrary grading of the size by such a method must lead to inaccuracy in the results. If the growth stages had been used as a standard of measurement, instead of I mm. increases in length, absolutely correct figures could have been obtained for each stage of the male and the female, and of the mature and the immature. It has been shown before, in Gammarus (Sexton, 1924), that all the individuals of a species go through a number (different for each species) of growth stages, marked off from each other by a moult, before they reach the full adult development; that each stage is characterized by an increase in size, in the number of joints of the antennae and pleopods, in the number of seta or spine clusters on the appendages, and, in the female, in the number of eggs in the broods laid in the successive breeding periods. Both sexes go through the same stages till sexual maturity is attained, after which the development is different, but, it must be noted, at any given stage, mature or immature, all the animals at that particular point are exactly alike, even to the number of setae and spines. The specific characters are constant, variation as such being unknown. 
I have not seen any of Höfken's material, but it is evident that he clearly recognizes the distinction between the species locusta and zaddachi, though it seems doubtful whether, in the low-salinity populations, he is dealing with the true locusta, or what is perhaps more likely, with Pirlot's species, the 'voisine de locusta' (p. 578).

The different points of the problem which he investigated are briefly:

(I) The question whether there is a continuous transition from locusta to zaddachi, and if so, whether it is connected with the geographical distribution. The conclusion from the statistical work on nine populations is that there is no continuous transition from one to the other, and that the whole material belongs to two different types, the one weakly and the other strongly bristled, 'the Locusta and the Zaddachi Types'. There were no intermediate forms found, i.e. animals in which all the characters take up an intermediate position between the types.

(2) The next point examined was the relation between the salinity of the habitats and the distribution of the types, and here, after quoting Schellenberg's summary of the observations of previous workers and his own, and Serventy's (1935) results on the Deben, Höf ken analyses his 'populations' and sums up by largely confirming Schellenberg's conclusions. These are that 'above a certain salinity, about $7 \%$, G. zaddachi occurs only when strong salinity variations take place; from $7 \%$ downwards, even if these are lacking, G. locusta can still flourish in exceptional cases at $4 \%$.'

The second method, breeding animals under changed salinity conditions very different from their original habitats, locusta in water of $6 \%$, zaddachi in $18 \%$ showed a far-reaching constancy of type unaffected by the changes in environment.

Höfken summarizes his results as follows: (I) A locusta type and a zaddachi type are to be distinguished; structurally they overlap each other, but each of them is in itself independent. (2) Each of these two types occupies its own area of distribution, which, however, in places overlaps that of the other type. (3) The distribution of the two types is chiefly dependent on the mean salinity and the salinity variations. (4) The locusta and the zaddachi types are by heredity fixed types, and invariable when exposed to changes in the salinity concentration.

\section{DESCRIPTION OF GAMMARUS ZADDACHI ${ }^{1}$}

Figures have already been given of the saline form from Bremerhaven (male in 1912, female in 1913). The freshwater form is now figured for the first time, and compared with adult saline animals of the same size.

The freshwater male represented was from the Hamburg water-supply collection (p. 58I), the saline male from Rauschen on the Baltic coast, Zaddach's collection. The figures of the true G. locusta (L.) (Pl. III), the species most often confused with zaddachi, are given to demonstrate their distinction.

The body is slender and laterally compressed, in the male larger, stronger, and more slenderly built and with stronger appendages than in the female. The chitinous cuticle varies in the two forms, being thick, strong and opaque in the freshwater, thin and semi-transparent in the brackish-water specimens. The former, also, carries a much denser supply of the characteristic long fine hairs on the antennae, peraeopods (particularly the hinder ones), pleon, 3 rd uropods and telson.

1 The terminology which I have used in this paper is that of Stebbing ("Amphipoda Gammaridea', Vol. 2I of Das Tierreich), and is as follows: body, consisting of head, peraeon, and pleon: head with ist and 2nd antennae; peraeon, with seven pairs of legs, two gnathopods, and five peraeopods; pleon segments $\mathrm{I}-3$ with three pairs of pleopods, segments $4-6$ (or 'urosome') carrying three pairs of uropods and telson. 
The body colour varies a little, much darker in some specimens than others, but is usually a pale yellowish green with bands of faint brown on the posterior margins of the body segments, the antennae, and other appendages. The females are generally darker than the males, more of a greyish green. Rathke gives the colour of his Crimean specimens as like weakly coloured joiners' glue in the male, dark grey in the female. The lateral patches of 'red oil-globules' on the first three pleon segments are very noticeable, bright red to purplish in colour. These red spots, noted by all the observers, were considered a distinguishing character of $G$. locusta at one time, whereas it is now known they are more or less developed in all the species of Gammarus.

Size and Sex. Compared with others of the genus, zaddachi is a fairly large species. There are many records of the male in favourable conditions, attaining a length of 20-22 mm.; the females are smaller, the largest about $15-17 \mathrm{~mm}$. Rathke gives Io lines for his Crimean specimens, I $\frac{1}{2}$ lines for the Norwegian animals. The measurements are taken along the dorsum with the specimen straightened out on a micrometer scale, from the tip of the rostrum to the insertion of the telson.

Sexual maturity is reached at about half-growth. Zaddach found many females ovigerous during the months of May and June I865 in Putziger Wiek, and in August I868 he collected four small females with eggs in Danziger Bucht, the largest about $9 \mathrm{~mm}$. There are many records from Britain of the species breeding from February to May.

No differentiation between the sexes can be seen in the newly hatched young, nor can it be traced till the sexual characters begin to appear several growth stages before maturity. Each growth stage ends with a moult, and by examining these moults it is possible to ascertain the state of the animal's development. This is more easily traced in the female in the brood-plates, which are attached to the ventral surface of the 2nd to the 5 th segments. When fully mature they show as large thin transparent lamellae, inset on the margins with long flexible fringing hairs which interlace to form the brood-pouch.

The number of stages before sexual maturity is reached in Gammarus varies with the species; in locusta, for example, eggs are laid after the I2th moult, in pulex after the Ioth, in chevreuxi after the 7th, and so on; but the development of the brood-plates appears to follow the same line in all the species observed. To take an example (Sexton, 1924, p. 345): in G. pulex where, owing to the thickness of the chitin, the moulted cuticle retains its firm outlines, it was possible to trace four stages of the developing brood-plates before full maturity. They first appeared in moult 7 as minute, rounded, leaf-like plates with margins entire; in moult 8 they had lengthened and increased to three times the size; in moult 9 rudimentary hairs were present on the margins; in moult to there was a great increase in size, and in the number of the rudimentary hairs, and the chitin was hard; in the next stage, sexual maturity was reached, the brood-plates were fully developed, with the long fringing hairs. In $G$. locusta the chitin is very thin in the young animals and tears so easily 
that it is difficult to find the first stages of the brood-plates; three were found, the stage of moult Io in locusta corresponding with moult 7 of pulex; that of moult I I with moult 9 pulex; and moult I 2 with moult Io pulex (i.e. the stage before full maturity).

This point is emphasized here, because of the fact that certain female intersexes of $G$. chevreuxi showed an arrested development of the brood-plates, marked by a great reduction of size, and by the rudimentary condition of the fringing hairs, resembling the immature stage (e.g. in moult 9 of pulex). So close is the resemblance that some collectors have recorded the young immature females with partially developed lamellae as 'intersexes', but the mistake could have been avoided if the age of the specimens had been noted. In the young animal, the sensory armature is sparse, the gills and brood-plates are small, while the female intersexes are larger and much more setose than the adult normals, with the gills much bigger, and the brood-plates very small in proportion, when compared with them.

The head (Pl. I, fig. I) measured along the dorsal line is about equal in length to the first two peraeon segments; in locusta it is definitely shorter. In both the freshwater and saline forms, the lateral lobes are obliquely truncate, with the upper angle produced, and subacute in the adults, rounded in the young and immature, as appears to be the case in the young of all the other species examined of the genus. Just below the angle and defining it is the indentation (Text-fig. I c) described by Pirlot as 'l'invagination de l'organe frontal. . . creusée à la face interne du lobe lateral'. In locusta (Text-fig. I $d$ ) the upper angle is sharply produced with the indentation small. A figure is given of this part of the lobe in wilkitzkii (Text-fig. I $e$ ) showing the extreme development of both the angle and the channelled indentation.

Eyes (see P1. I, fig. I, and P1. III, fig. I9) large, reniform, retinal pigment black with the interommatidial accessory pigment forming a thick white reticulation (not shown in the figures, as it tends to obscure the actual size of the lenses). The ommatidia are smaller and more numerous than in locusta, numbering about $170-180$ in the largest males. In the newly hatched young the eyes are quite round, as Zaddach (I878) was the first to point out and figure, and consist of about eight ommatidia.

Side-plates smaller than in locusta, about as deep as the corresponding segments; I-4 with two or three setules inset at the rounded anterior angle. The 4th (Pl. I, figs. 7, 9), which forms one of the distinguishing characters for the species, is as broad as deep, with the posterior expansion short and rounding into the almost semicircular margin, with three or four setules inset on the hind curve. In locusta the posterior expansion of the 4 th is very deep, with the hind margin straight, and with about thirteen setules inset on the curve. In both forms of zaddachi the posterior margins of the 5th, 6th, and particularly the 7 th side-plates are beset with long setiform spines, most numerous in the fresh-water animals.

Pleon, segments I-3 (Text-fig. I $a, b)$ : the ist epimeral plate is deeply notched 


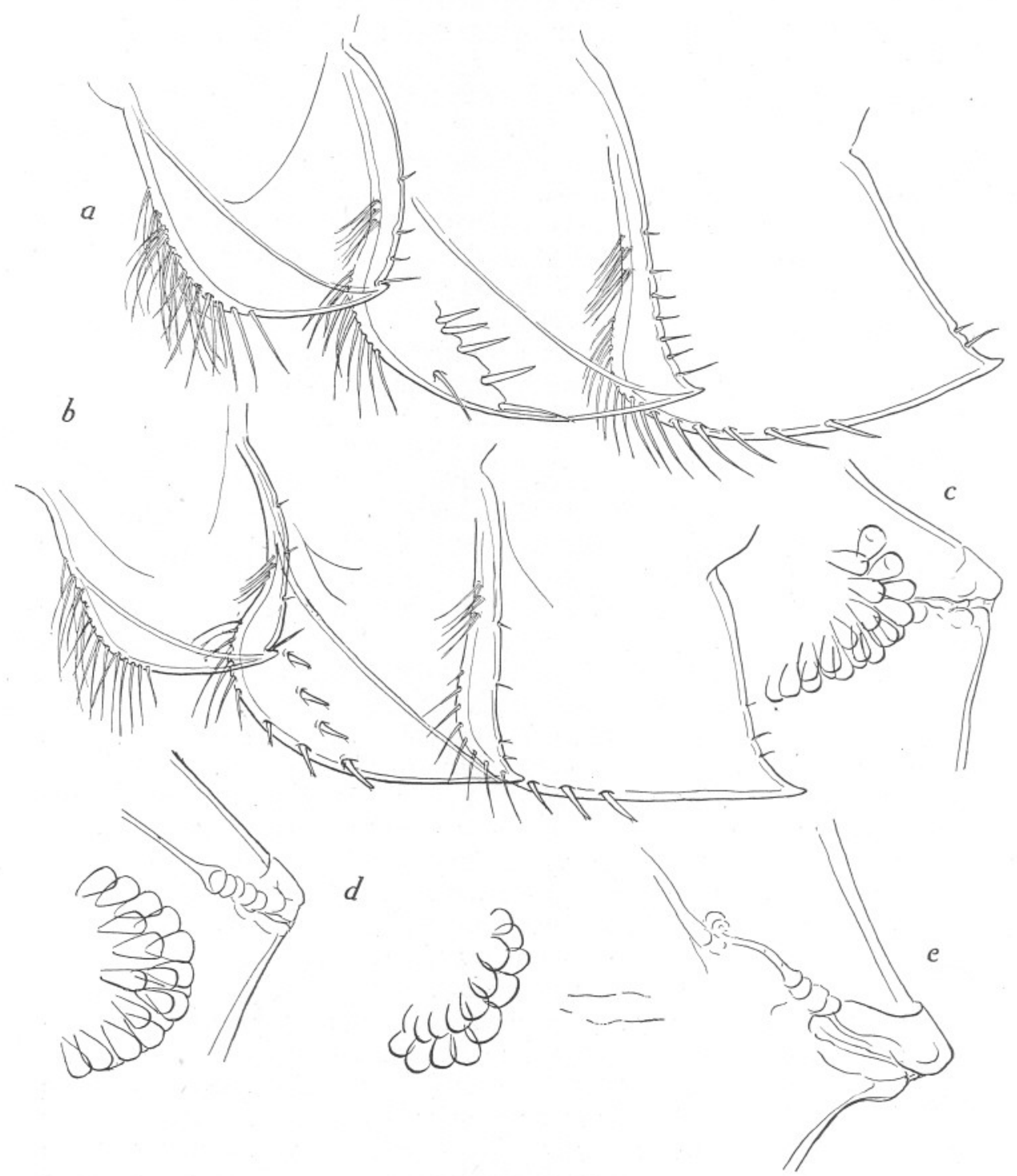

Text-fig. I. G. zaddachi, epimeral plates of pleon segments I-3, from the males figured in Pls. I and II: $a$, the freshwater form; $b$, the saline form. $\times 23 . c, d$ and $e$, upper angle of the lateral lobe of the head, right side, of G. zaddachi, locusta and wilkitzkii respectively, showing the opening connected with the frontal organ described by Pirlot, and the position of the eye in relation to the lobe in each species. $\times 75$. 
behind for the insertion of a seta, the 2nd and 3 rd are acutely produced backwards, though not to the same degree as in locusta. The difference between the two forms is seen plainly in the armature, the freshwater form having many more hairs anteriorly, and fewer and more slender spines inferiorly.

Segments 4-6 (P1. II, figs. I3, I8) slightly raised and rounded dorsally, each with the three spine groups. The number of the spines in these groups increases with age; the newly hatched young have only one spine in each group. In the adults the difference in the appearance of the two forms is more strongly marked here and in the hinder peraeopods than in any other part of the body, owing to the profusion of hairs developed in the freshwater animals. The spine formula for the saline form is usually $3: 2: 3 ; 3: 2 ; 3 ; 2: 2: 2$, with only a few short inconspicuous hairs between the spines, not exceeding them in length. Hoek (1889) gives the same formula for his 'locusta var. A', and Tesch (I915) for his male specimen, and $2: 2: 2$ on each of the three segments for the female. In the largest specimens from Rauschen the spines numbered $4: 2: 4 ; 4: 2: 4 ;$ and $3: 2: 3$; and Vanhöffen's (I9II) records are the same for his largest, with occasionally three instead of two in the first dorsal group. Rathke's largest Norwegian animals, $22 \mathrm{~mm}$., had five in the lateral clusters of 4 th and 5 th segments, three in 6th.

In the freshwater form the spines are usually fewer, $2: 2: 2$, on each of the segments, but the hairs are very numerous and very long, more than twice the length of the spines.

The antennae form one of the most striking distinguishing features of the species and the one most easily seen at first glance. In all the animals, saline as well as freshwater, both peduncles and the flagella carry on the under margin dense tufts or clusters of long stiff outstanding setae, some of each cluster extending far beyond the rest. The clusters in each joint are graduated in length to the distal angle, where the longest setae reach to three or four times the length of those in the proximal groups.

Antenna I (Pl. I, fig. I) is not quite half the length of the body; this measurement, though formerly much used in diagnosis, cannot be considered satisfactory or reliable. The antennae seem particularly subject to injury, judging by the number of broken or regenerating flagella one finds on going through a collection. Antenna $I$ is a little longer than antenna 2 in both sexes. The peduncle is unusually long for the genus, reaching in the adult to about half the length of the 5 th peduncle-joint of antenna 2 ; in the young the peduncles of the two antennae are equal in length. The ist joint, long and stout, is slightly longer than the 2nd in some specimens, subequal in others; the 3 rd joint is rather more than half the length of the Ist; all three joints bear clusters of graduated setae on the under margin. As has just been said, it is a little difficult to give an exact number for the joints of the flagella. Zaddach has $25-35$ for the primary and nine for the accessory; Hoek, for the male, 27-34, and 5-7; and for the female, $20-29$ in the primary and 4-6 in the accessory. The largest males in the collections examined had 36-44 for the one and 7-9 for the other. 
In addition to the long setae each joint in the primary flagellum from about the 5 th carries a small stalked sensory filament on the under-surface.

There should be no mistaking this species for $G$. locusta, the characterization is so distinct. In antenna $\mathrm{I}$, for instance, the peduncle in locusta is noticeably shorter in proportion, extending only to the distal end of the 4th joint of the peduncle of antenna 2 ; both peduncle and flagellum are almost glabrous, very sparsely provided with small setae (P1. III, fig. I9) and the accessory flagellum is much longer, I3-I4-jointed in the male, with about forty-seven joints in the primary. Poulsen (1932) also pointed out that the Ist peduncle joint in zaddachi bore long graduated clusters of setae, while in locusta there is only one hair on the under-margin in addition to the distal cluster.

Antenna 2 (Pl. I, fig. I) is stouter as well as shorter than antenna I. The 4th joint of the peduncle is slightly shorter than the 5 th, both having the characteristic graduated clusters of long setae. The flagellum is about as long as these two joints taken together, I5-I9-jointed in the largest males, furnished with clusters of setae, similar to those on the peduncle, less numerous in the female than in the male. Calceolae (Pl. I, fig. 2) occur in both sexes on the proximal joints, generally on succeeding joints from about the Ist (or 2nd) to the 6th or 7 th, then missing one joint, on the 8th or 9 th; e.g. a male $15 \mathrm{~mm}$. long with a I4-jointed flagellum, carried calceolae on the Ist to the 6th and 8th; in others of $17-19 \mathrm{~mm}$. with 15 -jointed flagellum the 1 st -7 th and 9 th joints were thus provided. The largest freshwater males $20-22 \mathrm{~mm}$. with $\mathrm{I} 7-\mathrm{I} 9$ flagellum joints, have II-I2 calceolae.

Gnathopods. On comparing zaddachi with locusta it will be noted that the hands in the former are much broader in proportion to their length, with the palm less oblique and the palmar spines of the adult male different in structure and in position. In the older specimens of zaddachi the spines are stout, truncate and microscopically ridged on the top; whilst those which characterize locusta, and appear to be peculiar to it (Pl. III, figs. 2I, 24), are flaskshaped, swollen at the base and constricted near the flat ridged top, with a strong central core. In duebeni the spines are strong, conical and pointed.

Gnathopod I (Pl. I, fig. 3). The hand of the male is oblong-oval, smaller than in gnathopod 2, and narrower in proportion to its length: palm and hindmargin are subequal; the palm crenulate, oblique, curving so as to end on the under-surface where the claw shuts down between the angle spine groups. One large truncate spine is situated midway on the palmar margin. The upper angle group contains six stout spines inset in pairs along the curve, the first pair consisting of one long sensory spine and one short and flat-topped, the other two pairs of short curved spines (Pl. I, fig. 4). The lower angle group also has six spines; one long sensory with two to three short curved ones inset facing the similar one on the upper side and a pair of the small bent spines below. The hind-margin carries about six rows of long stiff setae and serrated bristles.

In locusta, the hand of gnathopod I is smaller than in gnathopod 2, longer 
and narrower in proportion than in zaddachi, about twice as long as wide; the palm very oblique ending on the under-surface. One of the large peculiar flask-shaped spines is inset in the mid-margin; in the upper angle row are three graduated spines with swollen bases and a slight constriction above; in the under angle row there are one long spine and four small stout curved ones (Pl. III, figs. 20-22). The hind-margin has six rows of setae and serrated bristles.

Gnathopod 2 (Pl. I, fig. 5). The hand of the male is larger and broader than that of gnathopod I; it is roughly triangular in shape, the hind margin about two-thirds the length of the anterior margin and subequal with the palm. There is one large truncate spine in the mid-margin separated by a gap from the four graduated stout sensory spines at the palmar angle. A slight torsion brings the palm to end on the under-surface of the hand, where the claw closes down, with a pair of small stout spines near its tip. The hind margin carries nine to ten rows of long stiff setae and curved serrated bristles.

The female has one spine midway on the palm, and a more slender and pointed claw than the male.

In locusta (P1. III, figs. 23, 24) also, the hand is decidedly larger than in gnathopod I, but is narrower in proportion to its length than in zaddachi. It carries three of the peculiar flask-shaped spines on the palmar margin, one midway, and the other two spaced at intervals between it and the palmar angle. The upper angle row consists of six sensory spines inset in pairs. The claw impinges on the under-surface where, with a slight torsion as in zaddachi, the palm ends. The hind margin has about II-I2 rows of the long setae and bristles.

The peraeopods show a striking difference between the freshwater and the saline forms. The figures are taken from animals typical of the extremes of the species range to show the alteration in appearance caused by the development of the hairs particularly on the 4 th to the 6 th joints.

In the freshwater form (P1. I, figs. 6, 7; P1. II, figs. IO-I2) these joints carry dense clusters of very fine long hairs mixed with long slender spines; whilst at the other extreme, the 'spinose' effect of the saline form (P1. I, figs. 8,9 ; Pl. II, figs. I5-I7) is produced by the great reduction in the number and size of the hairs causing the spine clusters to show up conspicuously. The spines, too, are usually shorter and stronger and often more numerous than in the freshwater form. While these two types seem constant in their own particular environment, every grade of development of the sensory armature can be found in the 'intermediate' range, in the varying salinities, but whether these grades are correlated with the particular salinity of the locality in which they are captured, or whether they move up and down with the tidal movements in the estuaries, is not known.

The peraeopods in this species differ from locusta in various measurements, the $4^{\text {th }}$ joint, for example, being much shorter in proportion and broader; it is longer than the 6th in peraeopod I, about equal in peraeopod 2, and always shorter in the hinder peraeopods. 
Head

Lateral lobes

Eyes

Antenna I

Antenna 2

Side-plates

Pleon

Spine formula

Gnathopod I

Gnathopod 2

Peraeopods

Uropods

Telson

\section{G. zaddachi Sexton, I9I2}

As long as peraeon segs. I and 2 taken together. Sinus slight

Obliquely truncate, upper angle subacute; channelled indentation below connected with frontal organ

Large, elongate, reniform, broader than in locusta; ommatidia smaller, I70-180. Black

Peduncle long, reaching to half length of 5 th ped. jt. of ant. 2; Ist and 2nd joints subequal; 3rd more than half length of 2nd. Thick clusters of graduated hairs on all 3 joints ( 8 on jt. I: 8 on jt. 2 ; and 5 on jt. 3 ).

Primary flagellum 38-44; accessory flagellum 7-9

Shorter than ant. I. $4^{\text {th }}$ ped. jt. slightly shorter than 5th; both carrying clusters of graduated hairs ( 9 on jt. 4 ; Io on jt. 5 ). Flagellum I 5 jts.; with similar hairs and calceolae

As deep as corresponding segs. 4th as broad as deep; expansion short, inferior margin almost semicircular

Epimera of segs. 2 and 3, with hind-corners subacute. Dorsal humps only slightly raised

$$
\begin{aligned}
& 3: 2: 3 \\
& 3: 2: 3 \\
& 2: 2: 2
\end{aligned}
$$

Numerous long fine hairs in all the groups

Hand smaller than in gnath. 2; oblong oval, broad in proportion to length; I truncate spine, mid-margin of palm; angle group of 6 spines inset in pairs. Claw closes on undersurface

Hand roughly triangular. I truncate spine on palmar mid-margin, separated by a gap from the angle row of 4 spines

4th jt. shorter and broader in proportion than in others; hinder pps., basal jts. not much expanded; pp. 3 with hind-corner free; pps. 4 and 5 with spines inset at distal angle

Slender. Ur. I longest; inner ramus of ur. 3 always shorter than outer, about $\frac{3}{4}$ the length, with numerous long, feathered setae

Longer than broad; each lobe with apical group of 3 spines and hairs; subapical, I spine and I hair; subbasal, 2 spines and I hair

\section{G. locusta (L.)}

Distinctly shorter than peraeon segs. I and 2. Sinus slight

Angular; upper angle sharply produced

Large, elongate reniform; ommatidia large, about Ioo. Black

Peduncle shorter, reaching distal end of 4 th ped. jt., ant. 2 ; Ist jt. about as long as 2nd and 3rd combined; peduncle and flagella almost glabrous, only I seta on ped. jt. I under-surface.

Primary flagellum $40-47$, accessory flagellum $8-13$ or 14

Shorter than ant. I. 5th jt. about $\frac{1}{6}$ longer than 4 th; both with tufts of long fine hairs ( 9 on 4 th; 9 on 5 th). Flagellum 24 jts.; also with similar tufts and calceolae

Nearly twice as deep as corresponding segs. $4^{\text {th }}$ much deeper than broad; lower portion deep and almost rectangular

Segs. 2 and 3, hind-corners acutely produced. Dorsal humps elevated and prominent

$$
\begin{aligned}
& 4: 3-5: 4 \\
& 3: 4-5: 3 \\
& 3: 3: 3
\end{aligned}
$$

Spines and hairs shorter

Hand longer and narrower than in zaddachi; piriform; smaller than in gnath. 2; I flask-shaped spine on palmar margin; angle row of 3 spines. Claw much bent under

Hand much broader and stronger than gnath. I, narrower proportionately than in zaddachi. 3 flask-shaped spines on palm; angle group of 6 spines

Slender and elongate; hinder pps., only 3 rd pp. with hindcorner free, produced to an acute angle

Ur. 3 elongate, the 2 rami subequal in length, with numerous feathered setae and spines

Elongate; longer than broad; apical group of 3 spines, I hair; subapical, I spine, I hair; subbasal, 3 spines, 2 hairs

oิ 20-33 mm., f I $18-20 \mathrm{~mm}$. 


\section{FOUR OTHER SPECIES WITH WHICH IT HAS MOST OFTEN BEEN CONFUSED}

G. duebeni Liljeborg, I85I

Short; deep sinus

Vertically truncate; upper angle rounded

Rather smaller, reniform. Black

Ist ped. jt. not as long as 2nd and 3 rd combined, sparsely furnished with hairs.

Primary flagellum 25-34; accessory flagellum short, 5-6 jtd.

Much shorter than ant. I. 4 th and 5 th ped. jts. subequal. Flagellum stout, I II5-jtd. with calceolae

Deeper than corresponding segs.; 4th as broad as deep; expansion deep, rounding into inferior margin

Segs. 2 and 3 , hind-corners little produced, acutely quadrate. Dorsal humps not much raised

$$
\begin{aligned}
& 3: 2: 3 \\
& 3: 2: 3 \\
& 3: 2: 3
\end{aligned}
$$

Numerous long hairs

Hand subequal in size to gnath. 2; slender, conical, pointed spine in mid-margin; palm long and very oblique; angle row of 3 spines, and a pair inset on the hind-margin

Handovate, I slender pointed spine in mid-margin, another near angle row, almost continuous with it; angle row of 4 graduated pointed spines

Stouter; all 3 hinder pps. with hind corners free, produced in lobes; densely setiferous

Ur. 3 inner ramus much more slender than outer, and not much more than $\frac{1}{2}$ itslength; both rami densely setiferous, setae feathered

Shorter, broader and more spinose than in zaddachi; apical group of 4 spines and 7-9 hairs; subapical, I spine, 3 hairs; subbasal, 3 spines and 6 hairs

ơ $\mathrm{r} 3-\mathrm{r} 6 \mathrm{~mm}$.
G. pulex (L.), $\mathrm{I} 75^{8}$

Very short in proportion; sinus rather deep

Vertically truncate, but less broad than duebeni; upper angle rounded

Small, rounded oval. Black

Ist ped. jt. not as long as 2nd and 3 rd combined, almost glabrous.

Primary flagellum 24-28; accessory flagellum short, 3-4 jtd.

Considerably shorter than ant. I. 4th and 5 th ped.jts. subequal; with numerous short straight setae like bottle-brush. Flagellum I2-I3 jtd. with calceolae

Deeper than corresponding segs., 4th as broad as deep; posterior expansion deep and subrectangular

Segs. 2 and 3 very slightly produced; hind-corners quadrate. Dorsal humps slightly raised

$$
\begin{aligned}
& \text { I-2 }: 2: I-2 \\
& \text { I-2 }: 2: \text { I-2 } \\
& \text { I-2 }: 2: \text { I-2 }
\end{aligned}
$$

A few short hairs

Hand about same size as in gnath. 2; piriform; palm very oblique, crenulated; stout rounded spine in palmar mid-margin, angle row of 6 spines, inset in pairs. Claw closes underneath

Hand oblong, widening slightly at palm. Palm transverse and concave; I stout rounded spine in mid-margin; angle row of 3 spines

Slender. 3rd pp. has hindcorner free and rounded; pps. 4 and 5 with expansion wide and convex; hindcorners free, though small

Ur. 3 long; inner ramus about $\frac{3}{4}$ the length of the outer; numerous long feathered setae

Rather small, and sparsely armed; apical, 2 spines, 2 hairs; subbasal, I spine; and 2 groups of 2 hairs each inset between

oิ $12-20 \mathrm{~mm}$.
G.wilkitzkii Birula, I 897 (Arctic species)

Small in proportion; $\frac{2}{3}$ the length of peraeon. segs. I and 2; very deep sinus

Upper angle acutely produced; very deep sinus

Small, broadly reniform, only twice as long as broad. Black

Peduncle, Ist jt. longer and stouter than jt. $2 ; 3$ rd about $\frac{2}{3}$ as long as 2 nd. Peduncle reaches to about $\frac{1}{3}$ of 5 th ped. jt. ant. 2, all 3 jts. thickly beset with clusters of long hairs (8-9 on Ist jt.; $\mathrm{I}_{2}-\mathrm{I} 3$ on 2 nd; 7 on 3 rd). Primary flagellum 54-56; accessory flagellum 8-10

A little shorter than ant. I. 5th jt. of ped. longer and more slender than 4th; both ped. and flagellum with dense clusters of long hairs (I2-I3 on jt. 4 ; I3 $-I_{4}$ on jt. 5 ). Flagellum 24-28 (broken). Calceolae seen on $2 I$ jts.

A little deeper than corresponding segs.; 4th about as wide as deep; expansion very shallow, merging into semicircular inferior margin; angle hardly produced

Segs. 2 and 3 not much produced. Dorsal humps not much produced, lateral clusters at a different level (farther back on segments)

$$
\begin{aligned}
& 3: 2: 3 \\
& 3: 2: 3 \\
& 2: 2: 2
\end{aligned}
$$

Very numerous long straight hairs

Hand smaller than in gnath. 2; triangularly ovate; the whole limb thickly clothed with long hairs, many dentate spines on joints; palm very oblique; I stout conical spine mid-margin; and angle row of 5 graduated similar spines. Claw closes on under-surface

Hand very large and broad; palm almost transverse, only slightly oblique; I stout rounded median spine; and 5 graduated similar ones in angle row

Slender and elongate, with fewer spines and hairs than in zaddachi, 5th the longest and very slender; hinder pps., basal jts. successively longer and narrower: pp. 3 hind-corner produced, subrectangular; 4th and 5 th narrow to distal angle, where 2 long spines are inset

Ur. 3 inner ramus about as long as outer; both margins with long feathered setae

Longer and more slender in proportion; spines few, 2-3 in apical group; I subapical, and I subbasal

oิ $46-48 \mathrm{~mm}$. 
The basal joint in peraeopod 3 is expanded with the hind corner free and subacute; in peraeopods 4 and 5 it is narrowed distally, the hind corners not free but with one or two strong spines inset at the angle. In the older males the basal joints are long and very narrow, but in the females and immature they are always shorter and more expanded proportionately than in the adult male. The posterior margins of these joints in the saline form are inset with a few short hairs; in the freshwater forms the hairs are about three times the number and length.

The uropods (Pl. II, figs. I3, I4, I8). Uropod I is the longest; both uropod I and uropod 2 extend beyond the peduncle of uropod 3 , and both are furnished with more spines in the saline form. In locusta the rami of uropod 3 are subequal in length; in zaddachi the inner ramus is always shorter, about threequarters as long as the outer ramus in the adult, but the proportions vary with age and growth. In the newly hatched young, $\mathrm{I} .5 \mathrm{~mm}$., the inner ramus is not one-third the length of the outer. This character was first pointed out by Zaddach, as one of the principal features distinguishing his specimens from locusta. The figures show the development of the hairs and spines in the two forms.

The telson is about the length of the peduncle of the 3 rd uropods and is longer than broad. Each lobe is armed, in the saline form, with an apical group of three spines and two or three short hairs; a subapical group of one spine and one short hair; and a subbasal group of two spines and one hair: in the freshwater form, the apical group has three spines and 9-1o long hairs; the subapical, two hairs; and the subbasal one spine and two hairs; the hairs more than twice the length of the spines (P1. II, figs. I3, I8).

\section{SUMMARY}

Gammarus zaddachi is perhaps the most prolific and widespread of all the estuarine amphipods' known to occur in northern Europe, and inhabiting, as it does, the low-salinity estuarine zone and adjacent coasts, it has come to be recognized in recent ecological work as a 'salinity indicator'.

Unfortunately, there has been constant confusion with the other common species of Gammarus, G. locusta, pulex, and duebeni, which has been greatly complicated by the difference in the appearance of zaddachi according as it lives in a freshwater or a saline habitat. It is shown that this difference is entirely due to the sensory equipment, the greater production of hairs in freshwater conditions, and that the structure of the two 'forms' is identical.

The history of the species has been carried back as far as I have been able to trace it (I836) with the actual specimens, described in the different papers, and the more important of these papers are discussed. It will be seen that the material examined was derived from every country of northern Europe; from Russia, the White Sea, Crimea, and the Baltic, the coasts of Scandinavia, Germany, including the Hamburg water-supply, Denmark, the Netherlands, Great Britain and Ireland, and France as far up the Loire as Nantes. 
Detailed descriptions and figures of both forms of $G$. zaddachi are given; and finally, a comparison is made between the species most commonly confused with it, the Arctic species $G$. wilkitzkii being included because of a suggestion recently made that it might be, not a distinct species, but merely the Arctic form of zaddachi.

\section{REFERENCES}

BASSINDAle, R., I933. Abnormal eyes in wild Gammarus zaddachi Sexton. Fourn. Mar. Biol. Assoc., Vol. xIx, pp. 297-8.

- I94I. The Invertebrate Fauna of the Southern Shores of the Bristol Channel and Severn Estuary. Proc. Bristol Nat. Soc., Ser. iv, Vol. IX, Amphipoda, pp. I67-75.

BAte, C. SPENCE, 1862. Catalogue of the Specimens of Amphipodous Crustacea in the Collection of the British Museum, p. 206. London.

BAte, C. SPENCE \& Westwood, J. O., I863. History of the British Sessile-eyed Crustacea, Vol. I, pp. 378-83. London.

BRANDT, F., I85I. Reise in den äussersten Norden und Osten Siberiens während der fahre I843 und I844. Bd. II, Krebse., pp. I32-5. St Petersburg.

Chevreux, E., I899. Révision des amphipodes de la côte océanique de France. C.R. Assoc. franç. Avancem. Sci., $27 \mathrm{me}$ Sess., pp. 474-84.

Chevreux, E. \& J. DE Guerne, I892a. Sur une espèce nouvelle de Gammarus, du lac d'Annecy et sur les amphipodes d'eau douce de la France. C.R. Acad. Sci., Paris.

- I892 b. Description de Gammarus Delebecquei nov.sp. du lac d'Annecy, suivie de quelques remarques sur les Amphipodes d'eau douce de la France. Bull. Soc. Zool. France, T. xvir, pp. 136-42.

Crawford, G. I., I936. Additions to the Plymouth Marine Fauna (I93I) in the Crustacean Orders Tanaidacea, Isopoda and Amphipoda. Fourn. Mar. Biol. Assoc., Vol. xxI, pp. 95-I06.

- 1937. The Fauna of Certain Estuaries in West England, and S. Wales with Special Reference to the Tanaidacea, Isopoda and Amphipoda. Fourn. Mar. Biol. Assoc., Vol. xxi, pp. 647-62.

DAHL, FRIEDR., I893. Untersuchungen über die Thierwelt der Unterelbe. Sechster Bericht d. Komm. z. Wissenschaftl. Untersuchung. d. deutschen Meeres in Kiel I891, Bd. III, pp. I5I-85.

FABRICIUS, J. C., I775. Systema Entomologiae. Flensburgi et Lipsiae.

Fabricius, OtTo, I780. Fauna Groenlandica. Hafniae et Lipsiae.

GuRJANOVA, Eupraxie, I930. Beiträge zur Fauna der Crustacea-Malacostraca des arktischen Gebietes. Zool. Anz., Bd. 86, pp. 23I-48.

- I933. Contribution to the Fauna of Crustacea-Malacostraca of the Obj-Enisej Bay. Explor. de la Mer U.S.S.R., T. 18, pp. 75-90 (English summary).

Hellen, 1919. Zur Kenntnis der Amphipoden-Fauna Finnlands. Medd. Soc. Fauna Flora Fennica, Bd. 45.

HÖFKEN, UlRICH, I937. Statistische und experimentelle Untersuchungen über die Variabilität von Gammarus locusta (L.). Kieler Meeresforsch., Bd. II, pp. II6-48.

Hoek, P. P. C., I889. Crustacea Neerlandica. Tijdsch. Neder. Dierk. Ver., Ser. 2, D. II, pp. I70-234.

KLIE, W., I913. Die Crustaceen-Fauna des Alten Hafens zu Bremerhaven. Internat. Rev., Biol. Supp., Bd. vi (I2 pages).

Kraepelin, KarL, I886. Die Fauna der Hamburger Wasserleitung. Abh. a. d. Geb. Naturwiss. Verein in Hamburg, Bd. Ix, pp. 13-25. 
Linnaeus, C., I745. Ölandska och Gothlandska resa. Stockholm och Upsala. I758. Systema Naturae, Ioth and later editions. Stockholm.

MILNE EDWARDS, H., I830. Recherches pour servir à l'histoire naturelle des Crustacées Amphipodes. Ann. Sci. Nat., T. xx, pp. 353-99.

- I840. Histoire naturelle des crustacées comprenant l'anatomie, la physiologie, et la classification de ces animaux, T. III. Paris.

MöBIUS, KARL, I873. Die wirbellosen Thiere der Ostsee. Fahresber. Comm. Wissenschaftl. Untersuch. d. deutschen Meeres in Kiel I871. Translation, Dallas, I873. On the invertebrate animals of the Baltic. Ann. Mag. Nat. Hist., Ser. 4, Vol. xII, pp. 8I-9.

Montagu, George, I808. Description of several Marine Animals found on the South Coast of Devonshire. Trans. Linn. Soc. London, Vol. Ix, p. 92.

Oldevig, Hugo, 1933. Sveriges Amphipoder. Göteborgs Kung. Vetenskaps- och Vitterhets-Samhälles Handlingar. Femte Följden, Ser. B, Bd. 3, No. 4, pp. I97-9.

PALMER, Richard, I933. Notes on Gammarus zaddachi Sexton from Essex with observations on Eye-variations in this species. Ann. Mag. Nat. Hist., Ser. (I0), Vol. xI, pp. 64-7.

Percival, E., I929. A Report on the Fauna of the Estuaries of the River Tamar and the River Lynher. Fourn. Mar. Biol. Assoc., Vol. xvI, pp. 8I-I08.

Poulsen, E. M., 1932-3. On a Collection of Gammarus from the waters South of Sealand (30. 5. 1932). Vidensk. Medd. Naturh. Foren. Kjøb., Bd. 94, pp. I-I2.

Rathke, HeINRICH, I836. Zur Fauna der Krym. Mem. K. Akad. Wiss., Bd. III, pp. 82-4 (of original issue). St Petersburg.

- 1843. Beiträge zur Fauna Norwegens. Verhandl. d. K. Leopold-Carol. Akad.d. Naturf., Bd. xx, pp. 67-8.

RIECH, FrITZ, I926. Beiträge zur Kenntnis d. litoralen Lebensgemeinschaften in der poly- u. mesohaline Region d. Frischen Haffs. Schr. der Phys.-ökon. Ges. z. Königsberg i. Pr. Bd. Lxv, pp. 32-47.

SARs, G. O., I890. Crustacea of Norway. I. Amphipoda. p. 499.

SCHÄFERNA, KAREL, I922. Amphipoda Balcanica. Societas scientiarum bohemica, T. II (with English summary, p. 96).

SchellenBerg, A., I934. Zur Amphipoden-Fauna der Kieler Bucht. Schr. d. Naturwiss. Ver. für Schleswig-Holstein, Bd. xx, pp. I-I6.

— I937. Kritische Bemerkungen zur Systematik der Süsswassergammariden. Zool. Fahrb., Abt. Syst., Bd. 69, pp. 469-516.

SCHLIENZ, WALTER, I922. Systematische Bemerkungen zu den Gammarus-Arten aus Nord-deutschen Flussgeschwellen. Zool. Anz., Bd. LIv, pp. 215-17.

— 1923. Verbreitung und Verbreitungsbedingungen der höheren Krebse in Mündungsgebiet der Elbe. Arch. Hydrobiol., Bd. I4, pp. 429-52.

Serventy, D. L., I934. The Marine Invertebrate Fauna, in Scolt Head Island. Cambridge, pp. I96-213.

- 1935. Observations on Gammarus zaddachi Sexton, an Estuarine Amphipod and Associated Forms. Internat. Rev., Bd. 32, pp. 285-94.

Sexton, E. W., I9I2. Some brackish-water Amphipoda from the mouths of the Weser and the Elbe, and from the Baltic. Proc. Zool. Soc. London, pp. 656-65.

- r913. On a Collection of Gammarus from the Königsberg Museum. Schr. der Phys.-ökon. Ges. z. Königsberg i. Pr., Bd. LIv, pp. 90-4.

- I924. The moulting and growth stages of Gammarus with descriptions of the normals and intersexes of G. chevreuxi. Fourn. Mar. Biol. Assoc., Vol. xIII, pp. $340-401$.

- 1928. On the Rearing and Breeding of Gammarus in Laboratory Conditions. fourn. Mar. Biol. Assoc., Vol. xv, pp. 33-55. 
Sexton, E. W. \& Spooner, G. M., I940. An account of Marinogammarus (Schellenberg) gen.nov. [Amphipoda] with a description of a new species M. Pirloti. Fourn. Mar. Biol. Assoc., Vol. xxiv, pp. 633-82.

STEPHENSEN, K., I9I6. Zoogeographical Investigation of certain fjords in Southern Greenland with special reference to Crustacea, Pycnogonida, and Echinodermata. Medd. om Gronland, Bd. LIII, pp. 236-7.

- igr7. On a Collection of Gammarus from Randers Fjord Denmark. Vidensk. Medd. fra Dansk Naturh. Foren., Bd. 68, pp. 37-50.

1927. Revideret Fortegnelse over Danmarks arter af Amphipoda (3. Del Gammaridea. Fam. Gammaridae tel Fam. Podoceridae (Dulichiidae aut) Caprellidea). Vidensk. Medd. fra Dansk Naturh. Foren., Bd. 84, pp. II5-20.

- I928. Danmarks Fauna. Storkrebs. II. Ringkrebs. I. Tanglopper (Amphipoder). pp. 275-8. København.

- 1929. Die Tierwelt der Nord- und Ostsee. Lief. xIv, Teil xf. (Amphipoda). pp. $138-9$.

Stephensen, K. \& Ussing, H. J., I9I8. Krebsdyrene i Randers Fjord. In Randers Fjord Naturhistorie, kap. V.E., pp. 335-8. København.

SzIDAT, LOTHAR, I926. Beiträge zur Faunistik und Biologie des Kurischen Haffs. Schr. der Phys.-ökon. Ges. z. Königsberg i. Pr., Bd. 65, pp. 5-31.

Tesch, J. J., I9I5. Die Amphipoden der zuidelijke Noordzee verzameld met de 'Wodan'. Rapp. Rijksinst. Vissch. underzoek, D. I, pp. 336-9.

1922. Amphipoden: in Flora en Fauna der Zuiderzee, pp. 326-36. Helder.

VANHÖFFEN, E., I9II. Beiträge zur Kenntnis der Brackwasserfauna im Frischen Haff. Sitz. Ber. d. Ges. Naturf. Freunde, pp. 399-405.

- I917. Die niedere Tierwelt des Frischen Haffs. Sitz. Ber. Ges. Naturf. Freunde, pp. II3-47.

Volk, Richard, I907. Mitteilungen über die biologische Elbe-Untersuchung des Naturhistorischen Museums in Hamburg. Verhandl. d. Naturw. Ver. in Hamburg, Bd. 3, Xv, pp. I-54.

Walker, A. O., Igir. On Gammarus campylops Leach. Ann. Mag. Nat. Hist., Ser. (8), Vol. 7, pp. 397-9.

ZaDDach, E. G., I844. Synopseos Crustaceorum Prussicorum Prodromus. pp. 4-6. Regiomonti.

_ I878. Die Meeres-Fauna an der preussischen Küste. Schr. der Phys.-ökon. Ges. z. Königsberg i. Pr, I9. Jahrg., pp. 26-32.

I have not been able to consult Tesch, 1922, and Vanhöffen, I9I7.

EXPLANATION OF PLATES I-III

Plate I

Adult male, Gammarus zaddachi Sexton

Figs. I-7 show the freshwater form, from Hamburg Water-Supply; Figs. 8 and 9 the saline form from the Baltic.

Fig. I. Head and antennae. $\times 23$. (White reticulation not shown in eye.)

Fig. 2. One of the calceolae from the flagellum of antenna 2. $\times$ I40.

Fig. 3. Gnathopod I. 
Fig. 4. Distal portion of hand of gnathopod I. Under-surface, showing the torsion of the palm, the upper and under angle groups of spines with the claw closed down between them. (The long setae are omitted for the sake of greater clearness.) $\times 50$.

Fig. 5. Gnathopod 2, gill outlined. $\times 23$.

Fig. 6. First peraeopod, freshwater. $\times 23$.

Fig. 7. Second peraeopod, freshwater. $\times 23$.

Fig. 8. First peraeopod, saline, for comparison. $\times 23$.

Fig. 9. Second peraeopod, saline, for comparison. $\times 23$.

\section{Plate II}

Adult male, Gammarus zaddachi Sexton

Figs. I0-I4 freshwater form; Figs. I5-18 saline form; from the same males as in P1. I.

Fig. I0. Peraeopod 3. $\times 23$.

Fig. II. Peraeopod 4. $\times 23$.

Fig. I2. Peraeopod 5. $\times 23$.

Fig. 13. Pleon segments 4-6 with uropods $I$ and 2 , peduncle of 3 rd, and telson. $\times 23$.

Fig. 14. Uropod 3. $\times 23$.

Fig. 15. Peraeopod 3, saline, for comparison. $\times 23$.

Fig. I6. Peraeopod 4, saline, for comparison. $\times 23$.

Fig. 17. Peraeopod 5, saline, for comparison. $\times 23$.

Fig. 18. Pleon segments $4-6$, showing dorsal spines, uropods and telson. $\times 23$.

\section{Plate III}

Adult male, Gammarus locusta (L.)

Magnification less than in Pls. I and II.

Fig. 19. Head and antennae; white reticulation not shown in eye. $\times$ I2.

Fig. 20. Gnathopod I. $\times$ I2.

Fig. 2I. Distal portion of hand of gnathopod I, showing palmar spines-upper surface. $\times 28$.

Fig. 22. Distal portion of hand of gnathopod I, under-surface. $\times 28$.

Fig. 23. Gnathopod 2. $\times$ I2.

Fig. 24. Distal portion of hand of gnathopod 2 with palmar spines; turned over slightly to show palmar angle more clearly; long hairs omitted. $\times 28$. 


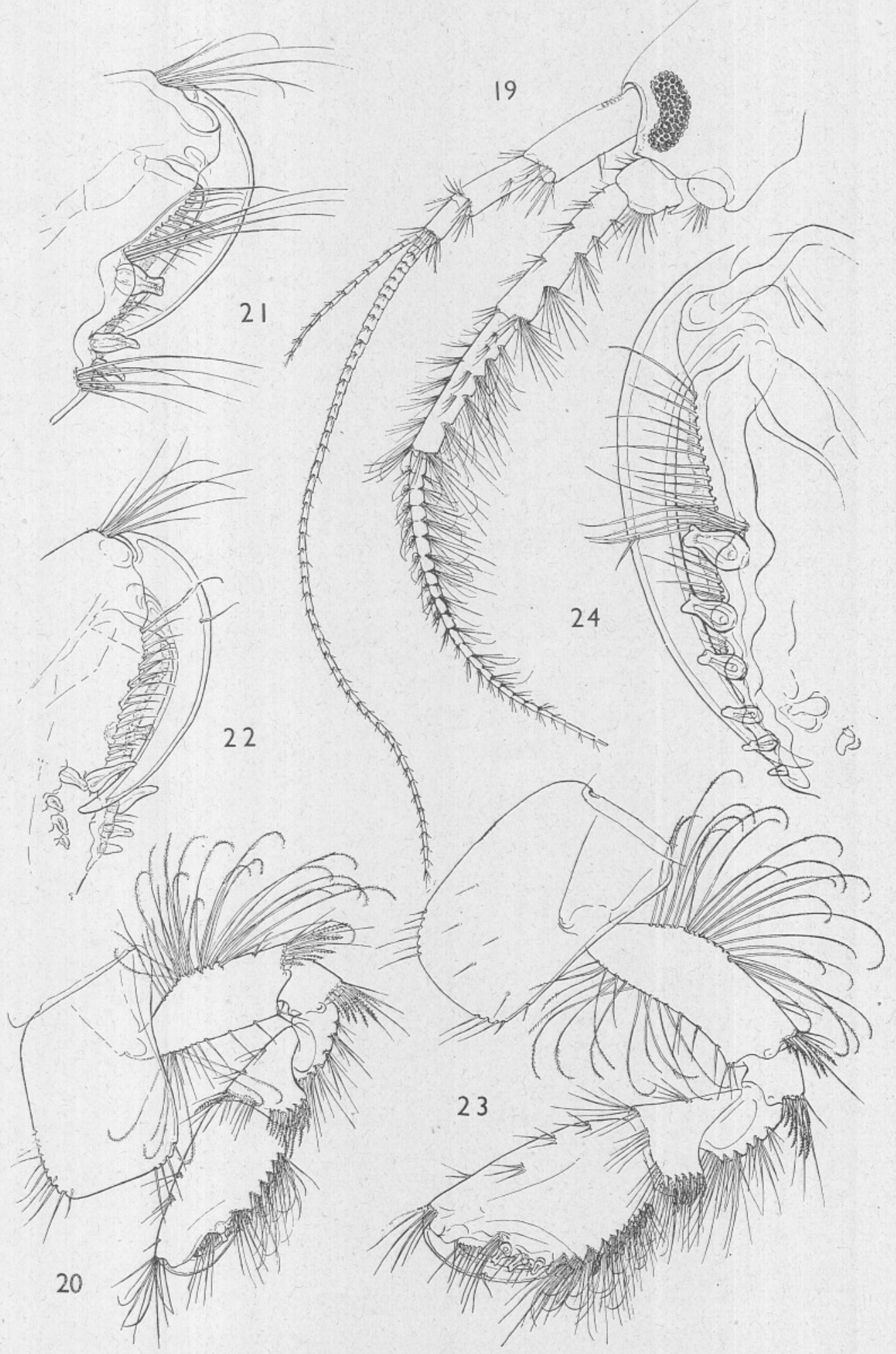

E. W. SEXTON del. 